\title{
ARTICLES
}

\section{EC COMPANY LAW DIRECTIVES AND REGULATIONS: HOW TRIVIAL ARE THEY?}

\author{
LUCA ENRIQUES*
}

\begin{abstract}
What role does European Community ("EC") legislation in the corporate law area play within the European Union ("EU")? How much does it shape Member States' corporate laws? And how relevant is it for the corporate governance of EU companies and their management? At first sight, the EC appears to have played and to be playing a central role in shaping EC corporate law, with the high number of directives and regulations covering a wide range of corporate law issues. One might then think that EC institutions have a strong influence upon Member States' corporate laws, whether because they have intervened in the area or because they may do so. Quite to the opposite, EC company law directives and regulations appear to have had very little impact on national

* University of Bologna and European Corporate Governance Institute. For helpful comments on earlier drafts of this article, I wish to thank: Riccardo Basso, Paulo Câmara, Carmine Di Noia, Eilis Ferran, Matteo Gatti, Jeffrey Gordon, Harald Halbhuber, Niamh Moloney, Federico Mucciarelli, Katharina Pistor, Mark Roe, Bruna Szegö, Marcello Tarabusi, Dirk Zetzsche; participants at the eleventh CLEF annual meeting at ETH (Zurich), at the Conference "EU Corporate Law Making: Institutional Structure, Regulatory Competition, and Regulatory Strategies," held at Harvard Law School on October 29-30, 2004, and at the ECGI and Oxford Review of Economic Policy Conference on Corporate Governance, held at the Saïd Business School in Oxford on January 28-29, 2005; and especially Brian Cheffins, Gérard Hertig, and Stefano Lombardo. I am also grateful to Bill Carney, who provided me with an unpublished appendix to an inspiring article of his, to Mette Neville, for a clarification on Swedish company law, and to Carlo Salodini for his valuable research assistance. The usual disclaimers apply.
\end{abstract}


company laws thus far and, more to the point, little impact on EU businesses' governance and management. First, EC corporate law does not cover core corporate law areas such as fiduciary duties and shareholder remedies. Second, EC corporate law rules are under enforced. Third, in the presence of very sporadic judiciary interpretation by the European Court of Justice, EC corporate law tends to be implemented and construed differently in each Member State, according to local legal culture and consistently with prior corporate law provisions. Fourth, when the EC has introduced new rules, it has done so with respect to issues on which Member States would have probably legislated even in the absence of an EC mandate. Last but not least, most EC corporate law rules can be categorized as optional, market-mimicking, unimportant, or avoidable. National corporate laws, on the other hand, contain core corporate law rules, which do have an impact upon EU companies' governance and management. There are, of course, due qualifications to the triviality thesis. First, a few rules or sets of rules indeed have had or are bound to have a meaningful impact upon companies and their operations. Second, EC corporate law has increased the regulatory burden of corporate laws across the EU, correspondingly securing more benefits in favor of certain interest groups. Third, secondary EC corporate law has had and will continue to have an impact on the evolution of European corporate laws and the dynamics of regulatory competition. Finally, its production has become an industry itself, employing many EC and national functionaries and lobbyists, and creating occasions for rent extraction by politicians. 
TABLE OF CONTENTS

1. INTRODUCTION.

.5

2. THE TRIVIALITY THESIS 1: SCOPE, ENFORCEMENT, INTERPRETATION, AND TIMING OF EC CORPORATE LAW

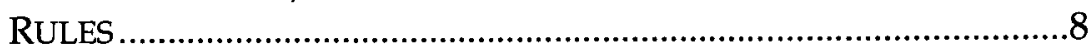

2.1. Scope of EC Corporate Law ..........................................11

2.2. Sporadic Enforcement, Parochial Interpretation ................12

2.2.1. Under enforcement............................................12

2.2.2. Does secondary EC corporate law really

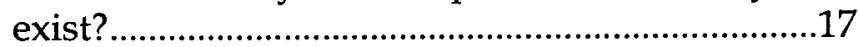

2.3. The Problem of "Hindsight Bias" ....................................20

3. THE TRIVIALITY THESIS 2: NATURE AND CONTENT OF EC

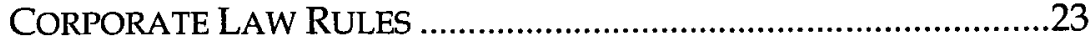

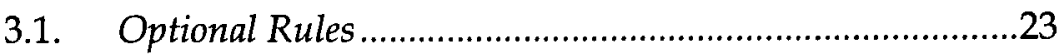

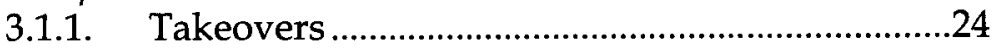

3.1.2. Accounting.......................................................26

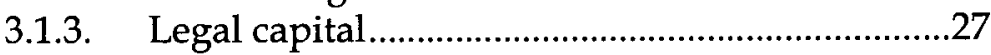

3.1.4. Preemption rights ...............................................29

3.1.5. Authority to bind the company .........................30

3.1.6. European Company Statute .................................31

3.1.7. Mutual recognition: the case of securities offerings....................................................................

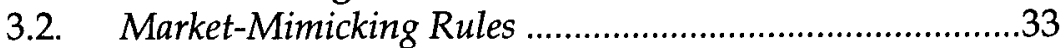

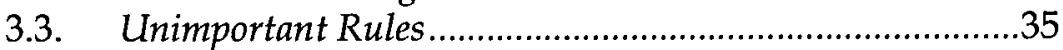

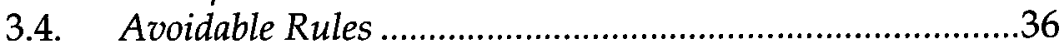

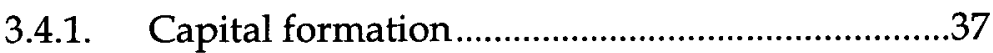

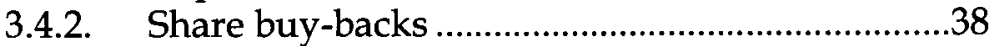

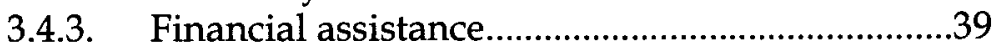

3.4.4. Major holdings ...................................................40

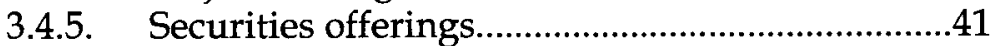

3.4.6. Mergers and divisions .........................................42

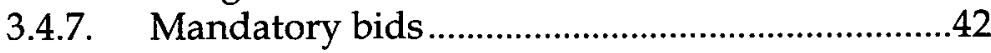

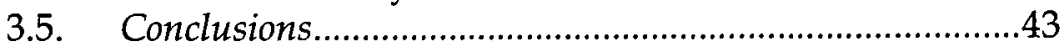

4. SOME QUALIFICATIONS TO THE TRIVIALITY THESIS AND ONE POSSIBLE OBJECTION ..........................................................44

4.1. Qualifications to the Triviality Thesis..............................44

4.1.1. The exceptions.......................................................44

4.1.2. Impact on the cost of doing business and on professionals' fees 
4.1.3. EC corporate law and the dynamics of EU national laws .........................................................50

4.1.3.1. Preeemptive changes of national corporate laws ...................................................50

4.1.3.2. EC corporate law as a cartel ......................51

4.1.4. EC corporate law legislation: a flourishing industry ................................................................55

4.2. One Possible Objection: Are Member States' Corporate Laws Also Trivial?..........................................65

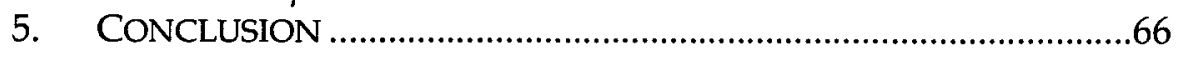

APPENDIX 1. EC CORPORATE LAW DIRECTIVES AND REGULATIONS .......................................................69

APPENDIX 2. ECJ CASES INVOLVING SECONDARY EC CORPORATE LAW ISSUES .......................................76 


\section{INTRODUCTION}

In a recent article on the dynamics of state competition for corporate charters in the United States, Mark Roe argues that Delaware's main competitor in making corporate law is the federal government." Since "Delaware players know that the federal government can take away their corporate lawmaking power in whole or in part," 2 the federal government has a heavy influence on the state's corporate law. ${ }^{3}$ This intuition, Roe argues, is confirmed by the history of Delaware law and federal politics, law, and regulation, ${ }^{4}$ and carries significant implications for the debate on competition for corporate charters in the United States. ${ }^{5}$ It is also relevant to the European debate on whether Centros and its progeny 6 can trigger regulatory competition within the EU. ${ }^{7}$ According to Roe, "those who analyze the EU's Centros debate need to understand that the full parallel [with the American race] brings Brussels... into the picture. Whether Brussels is effective, defective, or ineffec-

1 Mark J. Roe, Delaware's Competition, 117 HARV. L. REV. 588 passim (2003).

2 Id. at 592.

3 See id. at 591 (arguing that Washington often takes over economic issues of national importance, including corporate governance ones).

4 See id. at 600-34 (providing evidence supporting the view that the federal government can displace corporate law, inspire fear in Delaware players, and affect the corporate internal affairs of Delaware corporations); see also William W. Bratton, Corporate Law's Race to Nowhere in Particular, 44 U. TORONTO L.J. 401, 41825 (1994) (providing evidence of the threat of federal intervention in Delaware's corporate law). For a strong critique of Roe's thesis see Roberta Romano, Is Regulatory Competition a Problem or Irrelevant for Corporate Governance? 26-40 (March 2005), available at http://papers.ssrn.com/sol3/papers.cfm?abstract_id= 693484 (Eur. Corp. Governance Inst., Working Paper No. 26, 2005).

5 See Roe, supra note 1, at 634-43 (explaining that federal intervention undermines interstate competition for corporate charters).

6 See Case C-212/97, Centros Ltd. v. Erhvervs-og Selskabsstyrelsen, 1999 E.C.R. I-1459 (ruling that host Member States may not deny legally registered companies in other Member States the opportunity to conduct business); Case C208/00, Überseering BV v. Nordic Construction Company Baumanagement GmbH, 2002 E.C.R. I-9919 (holding that a host country must recognize a company created in a Member State that has moved its headquarters to the host country); C167/01 Kamer van Koophandel v. Inspire Art, 2003 E.C.R. I-10155 (holding that the fact that the company was formed in a particular Member State for the sole purpose of enjoying the benefit of more favorable legislation does not constitute abuse even if that company conducts its activities entirely or mainly in that second state).

7 See Roe, supra note 1, at 643-44 (claiming that European analysis should parallel the American analysis of intergovernmental influence).

Published by Penn Law: Legal Scholarship Repository, 2014 
tual affects the race." 8

While Member States are not now engaged in a competition for corporate charters, and cannot be expected to engage in one in the near future, ${ }^{9}$ the very presence of a centralized policymaker within the EU appears to play a role in determining the likelihood of a U.S.-style scenario, and more generally in the evolution of corporate laws ${ }^{10}$ within the Union.

This Article inquires into the role played by EC legislation in the sphere of corporate law. Sections 2 and 3 respond to the question of how far EC legislation actually shapes corporate laws in the various Member States, and, in short, how important it is for the governance and management of EU companies.

At first sight, the EC appears to play a central role in shaping EU corporate laws, here conceived broadly to include accounting law and securities law regulating issuers. EC harmonization measures under Article $44(2)(\mathrm{g})$ of the EC Treaty, ${ }^{11}$ now cover a number of areas, including formation of companies, distributions to shareholders, new issues of shares, mergers, divisions, accounting, auditing, mandatory disclosure, insider trading, takeovers, and so on. ${ }^{12}$ The EC has also created a European legal form, the European Company, which any medium-to-large EU business may adopt. ${ }^{13}$

8 Id. at 644.

9 See, e.g., Luca Enriques, EC Company Law and the Fears of a European Delaware, 15 EUR. Bus. L. REV. 1259 (2004) (arguing that a scenario similar to the American one, in which one or more European States engage in chartermongering, is highly unlikely); Tobias H. Tröger, Choice of Jurisdiction in European Corporate Law: Perspectives of European Corporate Governance, 6 EUR. BUS. ORG. L. REV. 3, 5 (2005).

10 This Article uses the terms "corporate law" and "company law" as synonyms. The terms "corporations" and "companies" are also used as synonyms.

11 Article $44(2)(\mathrm{g})$ of the Treaty Establishing The European Community, Nov. 10, 1997, 1997 O.J. (C 340), art. 44(2)(g) [hereinafter EC Treaty], grants the Council the power to "coordinat[e] to the necessary extent the safeguards which, for the protection of the interests of members and other, are required by Member States of companies or firms within the meaning of the second paragraph of Article 48 with a view to making such safeguards equivalent throughout the Community." tions.

12 Appendix 1, infra, provides the list of all relevant EC directives and regula-

13 In 1985, the EC introduced another legal form, the European Economic Interests Grouping ("EEIG"). Council Regulation 2137/85, 1985 O.J. (L 199) 1 (EC). However, the EEIG will not be considered in this Article because it is not considered a company in any meaningful sense: Member States are free to "determine whether or not groupings registered at their registries, pursuant to article 6, have legal personality." Id. art. 1, para. 3. Members" "participation" in the grouping 
One may think that, in the face of EC's pervasive intervention in the field, the European corporate law landscape is indeed similar to the American, as recently described by Mark Roe; that is, that EC institutions in Brussels have a strong influence upon Member States' corporate laws and, by implication, upon EU companies, either because they have already intervened in the area or because they may do so in the future. However, as we shall see, this is not the case.

Quite the opposite, existing EC corporate law is mostly trivial, in the sense that, with due but limited exceptions, it has very little impact on the way companies, and especially medium and large ones, are directed, managed, and controlled: first, EC corporate law does not cover such core areas as fiduciary duties and shareholder remedies; second, it is under-enforced; third, given the very sporadic judiciary interpretation of the European Court of Justice, EC corporate law tends to be implemented and construed differently in each Member State according to local legal culture and consistent with prior provisions; fourth, when it has introduced new rules, it has done so with respect to issues on which Member States would have most probably legislated even in the absence of an EC mandate; finally, most EC corporate law rules can be categorized as optional, market-mimicking, unimportant, or avoidable. As a result, EC directives and regulations play no significant role in addressing the agency problems stemming from the corporate form, because there is very little they prohibit, require, or enable. By contrast, national corporate laws, as argued in Section IV.B, contain the core rules, which do have an impact upon EU companies' governance and management.

Of course, the triviality hypothesis which is tested in Sections II and III does not apply to European Court of Justice case law in the area of freedom of establishment. Centros, Überseering, and Inspire $A r t^{14}$ have in fact made it somewhat easier for start-up and closely-

can only be transferred with the unanimous consent of other members. Id. art. 22, para. 1. Grouping's members are jointly and severally liable for the grouping's debts and liabilities of whatever nature. Id. art. 24, para. 1. Nevertheless, this legal form has been quite successful, especially in France and Belgium. See Libertas Institut Website, http:/ / www.libertas-institut.com/uk/uk_Vorlage.htm (last visited Feb. 15, 2006) (providing a list of 1598 EEIGs). For a discussion of legal personality, free transferability of shares, and limited liability as core features of corporations see REINIER KRAAKMAN ET AL., THE ANATOMY OF CORPORATE LAW 6-11 (2004).

14 See Case C-212/97, Centros Ltd. v. Erhvervs-og Selskabsstyrelsen, 1999

E.C.R. I-1459, 9920 (extending the mandatory recognition of company branches Published by Penn Law: Legal Scholarship Repository, 2014 
held companies to engage in regulatory arbitrage, ${ }^{15}$ which is already prompting national reforms of the regulation of such companies.16 However, these case law developments are beyond the scope of this Article, which deals with secondary EC corporate law, like directives and regulations.

Finding that, notwithstanding the steady stream of secondary EC corporate law rules over the last three decades, EC legislation is only marginally important for EU companies (other than smaller ones), Section IV qualifies the triviality thesis by identifying exceptions to it and by highlighting the major impact of directives and regulations in this area: they raise the cost of doing business by making it compulsory or highly advisable to obtain the advice of some professionals, such as accountants and lawyers, thereby securing these professionals' fees. Further, EC corporate law does affect the evolution of European corporate laws and, to some degree, the dynamics of regulatory competition. Finally, it has developed as an industry itself, employing a number of EC and State officials and lobbyists, and creating occasions for rent extraction by politicians. Section V concludes.

\section{THE TRIVIALITY THESIS 1: SCOPE, ENFORCEMENT, INTERPRETATION, AND TIMING OF EC CORPORATE LAW RULES}

Since 1968, the EC has adopted 37 directives ${ }^{17}$ and 10 regula-

between Member States); Case C-208/00, Überseering BV v. Nordic Construction Company Baumanagement GmbH, 2002 E.C.R. I-9919 (increasing the recognition of company status between and within Member States); Case C-167/01, Kamer van Koophandel v. Inspire Art, 2003 E.C.R. I-10155 (holding that companies may carry on their business in another Member State through a branch, and that the location of their registered office, central administration, or principal place of business serves as the connecting factor with the legal system of a particular Member State).

15 See, e.g., Enriques, supra note 9, at 1261 (describing how EU companies may reincorporate in other Member States in the post-Centros world).

16 An overhaul of Dutch corporate law is currently at its final stage. HarmJan de Kluiver, Inspiring a New European Company Law?, 1 EUR. CO. \& FIN. L. ReV. 121, 132 (2004). Meanwhile, France has eliminated the most apparent competitive disadvantage of French vis-à-vis English corporate law, i.e. minimum capital for (private) limited liability companies (sociétés à responsabilité limitée). Law No. 2003-721 of August 1, 2003, Journal Officiel de la République Française [J.O.] [Official Gazette of France], Aug. 5, 2003, p. 13449.

17 A directive is a legislative act which, according to article 249, EC Treaty, "shall be binding, as to the result to be achieved, upon each Member State to which it is addressed, but shall leave to the national authorities the choice of form and methods." EC Treaty, art. 249. National authorities have to transpose directives, which means introducing domestic laws and regulations consistent with https://scholarship.law.upenn.edu/jil/vol27/iss1/1 
tions ${ }^{18}$ in the area of corporate law, 19 and its output, after a decade or so of deep crisis, ${ }^{20}$ has been growing significantly since 2001 (Table 1).

TABLE 1. NUMBER OF EC COMPANY LAW DIRECTIVES AND REGULATIONS PER YEAR

\begin{tabular}{|l|l|}
\hline 1968 & 1 \\
\hline 1977 & 1 \\
\hline 1978 & 2 \\
\hline 1979 & 1 \\
\hline 1980 & 1 \\
\hline 1982 & 3 \\
\hline 1983 & 1 \\
\hline 1984 & 2 \\
\hline 1987 & 1 \\
\hline 1988 & 1 \\
\hline 1989 & 4 \\
\hline 1990 & 3 \\
\hline 1992 & 1 \\
\hline 1994 & 2 \\
\hline 1999 & 1 \\
\hline 2001 & 4 \\
\hline 2002 & 1 \\
\hline 2003 & 8 \\
\hline 2004 & 9 \\
\hline Total & 47 \\
\hline
\end{tabular}

Updated to December 31, 2004. Years in which no directives or regulations were adopted are omitted.

Undeniably, national corporate laws have changed as a conse-

them. In practice, the content of directives is often so specific as to leave national authorities little or no choice of form and methods.

18 A regulation is a legislative act that, again, according to article 249 of the EC Treaty, "shall have general application" and "shall be binding in its entirety and directly applicable in all Member States." Id.

19 There are ten "core" corporate law directives (including the Takeover Directive) and one "core" corporate law regulation. Eighteen measures deal with auditing and accounting issues (eleven directives and seven regulations). The remaining eighteen measures are in the securities law area (sixteen directives and two regulations). Of these eighteen securities law measures, ten have been repealed by directives consolidating or updating them. See infra Appendix 1.A.

20 See Klaus J. Hopt, Common Principles of Corporate Governance in Europe?, in The Clifford Chance Millennium LeCtures 105, 127 (Basil S. Markesinis ed., 2000) (describing the "political and other difficulties with company law harmonization" experienced by the European Commission during the 1990s). 
quence of the harmonization measures. ${ }^{21}$ As the European Commission itself put it in a recent Communication, "[o]ver the years, the EU institutions have taken a number of initiatives in the area of company law, many leading to impressive achievements.... [T]hese European measures have had an important impact on national company law." 22 This view is also shared by some European legal scholars. For instance, according to the Danish author of an EC company law treatise, "a quite comprehensive Community law regulation on most material aspects in the capital companies has been achieved." 23 Does this mean that EC rules have a real impact on the governance and management of EU corporations?24 As this and the following part argue, the answer is no: a closer look at the relevant directives and regulations reveals that EC corporate law, especially with respect to well established companies, is trivialdue to its scope, sporadic enforcement, and parochial interpretation-because it usually covers areas on which Member States had already or would have legislated anyway, and given that, as the

21 Uwe Blaurock, Steps Toward a Uniform Corporate Law in the European Union, 31 CORNELL INT'L L.J. 377, 383 (1998).

22 Communication from the Commission to the Council and the European Parliament: Modernising Company Law and Enhancing Corporate Governance in the European Union-A Plan to Move Forward, at 6, COM (2003) 284 final (May 21, 2003) (emphasis and footnotes omitted).

23 ERIK WERLAUfF, EU-COMPANY LAW 100 (2d ed. 2003) (emphasis omitted); see also PAUl Davies, GoWER \& DAVIES' PRINCIPLES OF MODERN COMPANY LAW 112 (7th ed. 2003) (describing the impact of EC law on United Kingdom company law as "substantial"); VANESSA EDWARDS, EC COMPANY LAW 1 (1999) ("[T]he prediction [by Clive Schmitthoff] of a truly European company law . . . may be described as significantly realized ....."); Karl Gleichmann, Perspectives on European Company Law, 14 FORUM INTERNATIONALE 3, 3-4 (1991) ("[T]he work of harmonizing national company law in the Community must be counted a success. This is shown not only by the number of directives that are in force.... It is also true when measured by the importance of the areas of the law that have been coordinated."); Benoît Lecourt, L'avenir du droit français des sociétés: que peut-on encore attendre du législateur européen? [The future of French corporate law: what can we still expect from the European legislator?], 2004 REVUE DES SOCIETES [2004 CORPORATIONS REVIEW] 223, 225 (entire areas of company law are under EC influence; harmonized rules have been an important factor of modernization for European firms); Jan Wouters, European Company Law: Quo Vadis?, 37 COMMON MKT. L. REv. 257, 258 (2000) ("[W]hat has been realized by the Community in the field of company and accounting law is impressive.").

24 Note that the question here is not whether EC secondary legislation in the corporate law area has helped achieve the objective of markets integration. See EILís FERRAN, BUILDING AN EU SECURITIES MARKET 36-41 (2004) (offering a skeptical assessment on EC securities law's role in the building of a single EU securities market). 
next Section argues, most of its rules are optional, marketmimicking, unimportant, or avoidable.

\subsection{Scope of EC Corporate Law}

The efforts to cover the core areas of corporate law have thus far failed. The Commission proposals on the corporate governance of companies and on company groups have never even been close to adoption, ${ }^{25}$ nor is there any evidence that they have affected national legislation in any way. ${ }^{26}$ As Harald Halbhuber notes, the directives that have been approved "do not purport to deal with crucial issues like fiduciary duties, exit, expulsion, and redemption, transfer of shares, etc.," and "[t]he legal rights and remedies of shareholders against the management of the company in the operation of the business, involving issues like derivative suits and directors' liability, and finally, the liability shield itself and ways to pierce it, remain matters of national law." 27

25 See, e.g., EDWARDS, supra note 23, at 387-91 (describing the legislative work done on these proposals and reporting that they have been "abandoned").

26 This is all the more true of the EC Commission's non-binding "recommendations." They are, in fact, usually ignored by Member States. See, e.g., Luca Enriques, Bad Apples, Bad Oranges: A Comment from Old Europe on Post-Enron Corporate Governance Reforms, 38 WAKE FOREST L. REV. 911,917 (2003) (remarking that recommendations are "not infrequently completely disregarded by Member States"). To be sure, whenever national policymakers happen to have the same policy agenda as the Commission, a recommendation may help make the case for that policy choice, lending it a European flavor and hence making it more appealing. But whenever the EC's and national policymakers' agendas differ, the impact of recommendations is nil. See id. (noting that the effectiveness of recommendations "relies on moral suasion and greatly varies from case to case," and that they serve primarily to "threaten[] hard law initiatives"). This justifies my decision here simply to ignore them. For the same reasons, the EC Commission's Communications in this area will also be ignored.

27 Harald Halbhuber, National Doctrinal Structures and European Company Law, 38 COMMON MKT. L. REV. 1385, 1406 (2001). See generally Jan Andersson, The High Level Group and the Issue of European Company Law Harmonisation - Europe Stumbles Along?, in THE REgUlation OF COMPANIES: A TRIBUTE TO PAUL KRÜGER ANDERSEN 183, 186 (Mette Neville \& Karsten Engsig Sørensen eds., 2003) (suggesting that "the legislative efforts of the EU have to a large extent ... been concerned with matters of lesser economic importance or at least with issues of relatively minor practical value"); CHRISTIAAN W.A. TIMMERMANS, COMPANY LAW AS IUS COMMUNE?: FIRST WALTER VAN GeRven Lecture, 3 (Wouter Devroe \& Dimitri Droshout eds., 2002), available at http://www.law.kuleuven.ac.be/ccle/pdf/wvg1.pdf (stating similarly that "attempts to harmonise classic issues of company law such as the institutional structure of the public company, minority protection, and directors' liability, failed"). 


\subsection{Sporadic Enforcement, Parochial Interpretation}

The impact of EC corporate law on individual jurisdictions is lessened by the well known fact that the enforcement mechanisms of EC corporate law are imperfect to say the least. ${ }^{28}$ Even more fundamentally, one can doubt that anything really worth calling EC corporate law exists "off the books."

\subsubsection{Under-Enforcement}

The Commission has traditionally lacked the resources to monitor Member States' compliance with corporate law directives; 29 no significant enforcement "from the bottom," in the form of European Court of Justice ("ECJ") preliminary reference procedures from national courts has ever made up for this. Thus far, the ECJ (which has no docket control) has decided upon fewer than twenty-five preliminary reference procedures dealing with secondary EC corporate law. ${ }^{30}$

28 See, e.g., Klaus J. Hopt, Company Law in the European Union: Harmonisation and/or Subsidiarity, 1 INT'L \& COMP. CORP. L.J. 41, 57 (1999) (discussing problems of enforcement in European company law).

29 See EDwARDS, supra note 23, at 10-11 \& n.58 (highlighting that the Commission's ability to monitor national implementation of company law directives and to pursue defaulting Member States before the Court of Justice "is circumscribed by practical limitations"); see also Gisbert Wolff, The Commission's Programme for Company Law Harmonisation: The Winding Road to a Uniform European Company Law?, in E.C. FinanCial Market Regulation AND COMPANY LaW 19, 24 (Mads Andenas \& Stephen Keynon-Slade eds., 1993) (lamenting the European Commission's lack of resources for the enforcement of company law directives). Thus far, the European Court of Justice ("ECJ") has decided no more than eleven proceedings against Member States for failure to implement corporate law directives. See infra Appendix 2.A for a listing of the cases. Nine of the proceedings concerned failure to implement directives within the deadline provided for in the directives themselves. One of them concerned failure to transpose two articles in a directive and only one dealt with the more substantive issue of whether the implementing rules had correctly transposed the directive's provisions. See infra text accompanying note 36. The EC Commission website reports ten infringement procedures in the area of "Company Law and Financial Reporting" between 1998 and 2004 (of these, five were brought in 2004). European Commission, Financial Reporting, Infringements Relating to Company Law and Financial Reporting, http://www.europa.eu.int/comm/internal_market/financial-reporting/infringe ments_en.htm (last visited Feb. 17, 2006). No infringement proceedings are reported in the same period with respect to securities directives and regulations. European Commission, Financial Services, Infringements, http://www.europa. eu.int/comm/internal_market/en/finances/infr/index.htm (last visited Feb. 15, 2006).

30 See infra Appendix 2.B. The preliminary rulings had been requested by courts from Greece (nine requests, for a total of seven rulings: in two instances https://scholarship.law.upenn.edu/jil/vol27/iss1/1 
Of course, Member States do implement directives, although often with considerable delay. However, major instances of implementing rules that are clearly at odds with the text of the directives can be found throughout the EU. To mention but one, in implementing the Fourth Council Directive of July 25, 1978, 31 Germany simply omitted a provision transposing article 2, paragraph $5 .{ }^{32}$

two cases were decided jointly), Germany (eight requests, for a total of seven rulings, with two cases being decided jointly on one occasion), the Netherlands (three), Austria (one), Belgium (one), France (one), and Spain (one). For comparison, just between 1998 and 2002 the Court decided upon or otherwise completed no fewer than 1,129 preliminary reference proceedings. See Statistics Concerning the Judicial Activity of the Court of Justice, in COURT OF JUSTICE OF THE EUROPEAN COMMunITIES, 2002 Annual Report 155, 160, available at http://curia.eu. int/en/instit/presentationfr/rapport/stat/st02cr.pdf (giving the number of preliminary reference proceedings for each of the five years). It is also interesting to note that sixteen out of the twenty-five cases involved proceedings between private parties and the state (as prosecutor or law enforcer in three cases, as bankruptcy administrator in eight of the nine Greek cases, as tax authority in two cases, as company register in two cases, and as regulator of auditors in one case). See generally infra Appendix 2.B.

31 Fourth Council Directive 78/660, 1978 O.J. (L 222) 11 (EC).

32 David Alexander, A European True and Fair View?, 1 EUR. ACCT. REV. 59, 64 (1993); see also Karel Van Hulle, The True and Fair View Override in the European Accounting Directives, 6 EUR. ACCT. REv. 711, 716 (1997) ("Some Member States (Germany, Austria, Finland and Sweden) were so unhappy about [the true and fair view concept] that they refused to fully implement it."). Article 2, paragraph 5 of the Fourth Council Directive provides that

[w] here in exceptional cases the application of a provision of this Directive is incompatible with the obligation laid down in paragraph 3 , that provision must be departed from in order to give a true and fair view within the meaning of paragraph 3 . Any such departure must be disclosed in the notes on the accounts together with an explanation of the reasons for it and a statement of its effect on the assets, liabilities, financial position and profit or loss. The Member States may define the exceptional cases in question and lay down the relevant special rules.

Fourth Council Directive, supra note 31, at 12.

Germany decided not to introduce a provision expressly transposing article 2, paragraph 5 of the Fourth Council Directive on the grounds that it was superfluous: such an implementing rule would only have stated explicitly what could be derived from a general principle in German law according to which rules have to be construed consistently with the Directive's legislative intent as expressed in article 2. See, e.g., MATHIAS HABERSACK, EUROPÄISCHES GESELLSCHAFTSRECHT [European Corporate Law] 233 n.47 (2nd ed. 2003) (reporting that this view was endorsed by the government commission in charge of drafting the rules implementing the Fourth Council Directive); Dieter Ordelheide, True and Fair View: A European and a German Perspective, 1 EUR. ACCT. REv. 81, 86 (1993) ("The so-called functional interpretation of the law can be regarded as an equivalent to the overriding property of the true and fair view of Art. 2 (5)."). Although, as is argued imPublished by Penn Law: Legal Scholarship Repository, 2014 
More insidiously, Member States have sometimes failed to enforce implementing rules. Again, Germany provides a case in point with respect to the obligation to disclose annual accounts as imposed by the Fourth Council Directive. ${ }^{33}$ Although most private companies ("GmbHs") failed to comply, no sanction ever followed, because the rules on sanctions had been crafted in such a way as to make them practically impossible to apply. ${ }^{34}$ Fifteen years after the deadline for the implementation of the relevant EC provisions, 35 the ECJ finally declared that Germany had failed to comply with its obligations under EC law. ${ }^{36}$ Despite changes in the rules governing the disclosure obligation so as to make it easier for sanctions to be applied, ${ }^{37}$ most German companies still fail to disclose their accounts. ${ }^{38}$ This warrants the suspicion (admittedly, only the suspicion) that the accounting rules implementing the Fourth Council Directive may also be commonly violated: in the absence of disclosure to the public, there is definitely less incentive to provide true and fair accounts. ${ }^{39}$

mediately below, it is impossible to tell what the content of an EC corporate law provision is until the ECJ decides upon it, it would be surprising if article 2, paragraph 5 of the Fourth Council Directive were to be construed as simply meaning that the specific provisions of the Fourth Council Directive have to be construed according to the legislative intent. See Axel Haller, Financial Accounting Developments in the European Union: Past Events and Future Prospects, 11 EUR. ACCT. REv. 153, 157 (2002) (stating that the true and fair view principle "de facto ranks professional judgment higher than codified rules or standards").

33 Fourth Council Directive, supra note 31, art. 47, para. 1, at 27.

34 See generally EDWARDS, supra note 23, at 26-28 (noting that the Court of Justice held in three cases that a directive may not impose obligations on an individual). Similarly, in Spain "the law does not establish a penalty for not [depositing annual financial statements in the Registro Mercantil] unless the company goes bankrupt. This implies that not all firms, especially the smaller ones, comply with this obligation..." María Gutiérrez \& Josep A. Tribó, Private Benefits Extraction in Closely-Held Corporations: The Case for Multiple Large Shareholders 7 (Eur. Corp. Governance Inst., Fin. Working Paper No. 53/2004, 2004).

35 See Fourth Council Directive, supra note 31, art. 55, paras. 1-2, at 29 (establishing deadlines for incorporating into national law and bringing into force the provisions of the Fourth Directive). 5464.

36 Case C-191/95, Comm'n v. Fed. Republic of Germany, 1998 E.C.R. I-5449,

37 See, e.g., HABERSACK, supra note 32, at 69.

38 See Franz Jürgen Marx \& Holger Dallmann, Jahresabschlusspublizität Mittelständischer Unternehmen [Annual Publication of Medium-Sized Companies], 59 BETRIEBS-BERATER [COMPANY CONSULTANT] 929 (2004) (providing empirical evidence that shows that more than 90 percent of German firms still fail to disclose their accounts).

39 Not to mention that, in Germany, annual accounts prepared according to https://scholarship.law.upenn.edu/jil/vol27/iss1/1 
EC securities law, as the Lamfalussy Report recognized,40 is also a field in which Member States have often violated Community law with very little subsequent EC enforcement. ${ }^{41}$ It is too early to tell whether the new wave of securities directives, ${ }^{42}$ together with the Lamfalussy architecture and especially its Level 3 and Level 4 regulatory tools, ${ }^{43}$ will change this state of affairs. ${ }^{44}$

company law rules are also relevant for tax purposes, which, of course, does not encourage compliance with the true and fair view principle. See, e.g., Haller, supra note 32 , at 157 .

40 See Final Report of the Committee of Wise Men on the Regulation of European Securities Markets 14-15 (Feb. 15, 2001), http://europa.eu.int/comm/internal_market/securities/docs/lamfalussy/wisemen/final-report-wise-men_en.pdf (noting various difficulties the EC faces in passing legislation). The Committee was chaired by Alexandre Lamfalussy.

41 See, e.g., NiAmH MolONEY, EC SECURITIES Regulation 153-54 (2002) (noting that Council Directive 80/390, 1980 O.J. (L 100) 1 (EC), lacks stringent enforcement and damages provisions); Karel Lannoo, A European Perspective on Corporate Governance, 37 J. COMMON MKT. STUD. 269, 282 (1999) (noting inadequate enforcement of the first insider trading directive, Council Directive 89/592, 1989 O.J. (L 334) 30, and a directive regarding information disclosure, Council Directive 88/627, 1988 O.J. (L 348) 62); see also supra note 29 and accompanying text. Katharina Pistor suggests that accession countries may have adopted a "comply but don't enforce strategy" with respect to EC corporate law measures such as Directive 88/627. Katharina Pistor, Enhancing Corporate Governance in the New Member States: Does EU Law Help?, in LAW AND GOVERNANCE IN AN ENLARGED EUROPEAN UNION 339, 352 (George A. Bermann \& Katharina Pistor eds., 2004).

42 For a complete list of these see infra Appendix 1.

43 Under the "Lamfalussy Process," "the key objective of Level 3 [is] to ensure consistent, timely, common and uniform implementation of Level 1 and 2 acts in Member States, via enhanced co-operation and networking among EU securities regulators," while "[a]t level 4, the Commission and the Member States would strengthen the enforcement of Community law." Gerard Hertig \& Ruben Lee, Four Predictions About the Future of EU Securities Regulation, 3 J. COMP. L. STUD. 359,363 (2003). See infra text preceding note 207 for a brief description of the Lamfalussy approach's Level 1 and Level 2 measures.

44 According to an experts group appraising the impact of the Financial Services Action Plan, "at present, enforcement is not sufficiently effective, in particular because of lack of political impetus, infringement procedures that are too timeconsuming and insufficient allocation of Commission resources." European Securitisation Forum, Sec. Expert Group, Financial Services Action Plan: Progress and Prospects, Final Report 17 (May 2004), available at http:// www.europeansecuritisation.com/pubs/FSAP_Stocktaking_Report.pdf; see also Hertig \& Lee, supra note 43 , at 367 (expressing the view that the Lamfalussy method will fail to solve the problem of weak enforcement of EC securities law).

Similarly, it has been argued that the recent steps forward in EC accounting regulation, and especially the adoption of International Financial Reporting Standards, may have less impact than commonly expected, due to the fact that, as recent scandals in the United States and in Europe have shown, proper enforcement of accounting rules is crucial and, at present, left totally to Member States. See Ka- 
A process of "intentional or unintentional erosion" 45 may also take place, by which new national laws modify rules implementing $\mathrm{EC}$ directives in a way inconsistent with the latter, a phenomenon "which may well occur without the Community authorities being aware of it or being in a position to evaluate its impact." 46

Good examples of erosion can be found in recent corporate law developments in Italy. The comprehensive corporate law reform of 2003 blatantly violates the Second Council Directive ${ }^{47}$ in several respects. For instance, contrary to article 18, paragraph 1 of the Second Council Directive, which bans subscription of own shares outright, article 2357-ter, paragraph 2 of the Italian Civil Code now provides that the shareholders' meeting may authorize the company to exercise the preemptive rights pertaining to its treasury shares and thus to subscribe its own shares. ${ }^{48}$ Additionally, against the Second Council Directive's article 13, the provisions on conversion of companies do not require an expert report assessing that the value of the net assets of a private limited liability company ("società a responsabilità limitata") being converted into a public company ("società per azioni") corresponds at least to the transformed entity's legal capital. 49

Finally, the fact that directives have no direct horizontal effect further dulls the impact of EC legislation on corporate law within the Member States. As the ECJ has frequently reiterated, directives are addressed to Member States, and private parties cannot invoke them in relationships with other private parties.50 This means that

rel Lannoo, The Emerging Framework for Disclosure in the EU, 3 J. CORP. L. STUD. 329, 352 (2003) (pointing out that the challenge will be to ensure uniform enforcement across the EU).

45 Richard M. Buxbaum \& Klaus J. Hopt, Legal Harmonization and the BUSINESS ENTERPRISE 265 (1988).

46 Id.

47 Second Council Directive 77/91, 1977 O.J. (L 26) 1.

48 See Giuseppe B. Portale, Riforma delle società di capitali e limiti di effettività del diritto nazionale [The new corporate law and lack of effects in the national law], in LE SOCIETÀ 261, 264 (2003) (noting that article 2357-ter violates the Second Council Directive and providing another example of erosion concerning the $\mathrm{EC}$ rules on divisions).

49 See Luca Enriques, Spunti in tema di strumenti finanziari partecipativi e ibridi e di azioni correlate e riscattabili (con un caveat sulle trasformazioni elusive da S.r.l. a S.p.a.) [Cues about securities and correlated and redeemable stocks (with a caveat on the elusive conversions from a Limited liability company to a Public company)], in NuOvo DIRITTO SOCIETARIO 107, 112-13 (Maurizio de Tilla et al. eds., 2003).

50 See, e.g., Case 152/84, M. H. Marshall v. Southampton and South-West Hampshire Area Health Authority (Teaching), 1986 E.C.R. 723, para. 48 (providhttps://scholarship.law.upenn.edu/jil/vol27/iss1/1 
national company laws that conflict with a directive remain in effect with regard to private parties until they are repealed by the national legislature, even if in the meantime the ECJ finds that they are in violation of the directive. To be sure, the Court has also held that, in applying national law, national courts must construe the national law, "as far as possible, in the light of the wording and the purpose of the directive in order to achieve the result pursued by the latter." 51 In fact, as the Marleasing case shows, such a requirement may actually produce an outcome that closely resembles direct horizontal effect. ${ }^{52}$

\subsubsection{Does secondary EC corporate law really exist?}

An even more fundamental question may be raised about EC corporate law. Is there any secondary EC corporate law apart from the interpretation the ECJ has provided in the nineteen rulings thus far issued? ${ }^{53}$ Harald Halbhuber has convincingly shown that national doctrinal structures "filter European legal materials," so that one may question whether EC corporate law "means the same for lawyers from different Member States." 54 More specifically, he shows how German lawyers' national legal culture led them to

ing that a directive may not impose obligations on an individual and, correspondingly, a provision of a directive may not be relied upon against an individual). Directives may have a direct "vertical effect," i.e., be applicable to the relationship between a private party and a Member State, possibly giving a private party that is harmed by the failure to implement a directive the right to claim damages from the State. See, e.g., PAul CRAIG \& GRÁINNE DE BúrCa, EU LAW: TeXT, CASES, AND MATERIALS 115 (3d ed. 2002) (noting that the ECJ decisions have enabled individuals to rely on directives at least on actions against the state).

51 Case C-106/89, Marleasing SA v. La Comercial Internacional de Alimentación SA, 1990 E.C.R. I-4135, I-4159 (emphasis added).

52 Cf. WERLAUFF, supra note 23, at 66-67 (citing the Marleasing case as an example of how directives may turn out to have a direct horizontal effect as an outcome of the interpretation of national rules in light of EC ones). The ECJ held that article 11 of the First Directive required Spanish courts to de facto disregard the Civil Code provisions according to which companies without cause (purpose) are void. Marleasing, 1990 E.C.R. at I-4159. Article 11 contains an exhaustive list of grounds for a declaration of nullity of a company - lack of cause is not included. First Council Directive 68/151, art. 11, 1968 O.J. (L 65) 43.

53 Out of these nineteen rulings, one is an enforcement action against Germany by the Commission, Case C-191/95, Comm'n v. Fed. Republic of Germany, 1998 E.C.R. I-5449, and eighteen are preliminary rulings proceedings, see infra Appendix 2.B. Moreover, six (those given in the Greek cases) deal with the same question, while three deal with very specific questions concerning the Fourth Directive. See infra note 65.

54 Halbhuber, supra note 27, at 1385.

Published by Penn Law: Legal Scholarship Repository, 2014 
"misread crucial [ECJ] case law [on companies' freedom of establishment] for over a decade," 55 and to "overstate the harmonization actually achieved" 56 through corporate law directives.

A good example of this tendency to "nationalize" EC corporate law can be found in Italian corporate law scholarship. Italian legal scholars tend to construe the Second Council Directive's provision that " $[t]$ he subscribed capital may not be reduced to an amount less than the minimum capital laid down in accordance with article $6,{ }^{\prime \prime 57}$ as adopting the recapitalize or liquidate rule ${ }^{58}$ which the Italian Civil Code imposes upon Italian companies, ${ }^{59}$ while in fact the Council Directive's provision "only forbids formal capital reduction below that threshold [by the shareholders' meeting]." 60

Similarly, in German legal scholars' view it is absolutely settled that article 15 of the Second Council Directive applies not only to dividends, but also to any kind of distribution and hence, also to hidden distributions, i.e. to "an exchange of economic goods between the corporation and a shareholder (or a person close to a shareholder) at terms that the corporation would not have agreed to when dealing with an unrelated third party."61 While the Germans may well be right in holding that this is the correct interpretation of article 15, it is also unquestionable that in England, where courts also find hidden distributions illegal, commentators and courts "appear not to see a connection with the Second [Council] Directive," 62 while in other jurisdictions transactions between the

55 Id. at 1386; see also id. at 1387-99 (discussing German authors' idiosyncratic interpretation of the ECJ company law cases from Daily Mail, Case 81/87, The Queen v. H.M. Treasury and Comm'r of Inland Revenue, ex parte Daily Mail and General Trust PLC, 1988 E.C.R. 5483, to Case C-212/97, Centros Ltd v. Erhvervsog Selskabsstyrelsen, 1999 E.C.R. I-1459.

56 Halbhuber, supra note 27, at 1407.

57 Second Council Directive 77/91, supra note 47 , art. 34 .

58 See infra text accompanying to notes 262-264.

59 Codice civile [C.c.]. art. 2447 (Italy); see, e.g., Francesco Denozza, Le società [Corporations], in 1 I CINQUANT'ANNI DEL CODICE CIVILE 321, 323 (1993).

60 Luca Enriques \& Jonathan R. Macey, Creditors Versus Capital Formation: The Case Against the European Legal Capital Rules, 86 CORNELL L. REv. 1165, 1183 (2001).

61 Peter O. Mülbert \& Max Birke, Legal Capital-Is There a Case Against the European Legal Capital Rules?, 3 EuR. BuS. ORG. L. REV. 695, 706 (2002); see also id. at 705-06 ("[E]ven before the promulgation of the Directive, German courts had laid down the groundwork of an intricate system of rules on... 'hidden distributions."').

62 Luca Enriques \& Martin Gelter, The Relationship Between Creditors and Corporate Debtors: Regulatory Competition and Cooperation Within the EU, 7 EUR. BUS. ORG. L. REV. (forthcoming) (manuscript at 10, on file with authors). 
corporation and shareholders entered into at unfair terms are simply not treated as unlawful distributions. ${ }^{63}$

Even apart from nationalistic tendencies in the interpretation of EC corporate law, there are instances in which core provisions in the directives themselves cannot reasonably be construed uniformly because different versions in different languages are incompatible. The most prominent case is article 2, paragraph 3, of the Fourth Council Directive which adopts the overriding principle that " $[t]$ he annual accounts shall give a true and fair view of the company's assets, liabilities, financial position and profit or loss." As accounting scholars have shown, not only are the English and the German versions of article 2 in no way direct translations of one another, but they "do not appear to say or mean the same thing." 64 If this is the case, it is no wonder that interpretations of article 2, perhaps the core EC accounting law provision, are different in the various countries. 65

To conclude on this point, with the possible exception of the few and narrow interpretative issues clarified by ECJ rulings, and no matter what truly EC-minded and ECJ-educated legal scholars argue, the prevailing interpretation of any given directive in each jurisdiction is, wherever possible, an interpretation compatible with the existing legal culture. In other words, tradition and pre-

63 Id. (discussing France and Italy).

64 Alexander, supra note 32, at 63.

65 See id. passim (showing that the interpretation of the true and fair view principle is different in the United Kingdom, Germany, and France); see also Haller, supra note 32, at 157 (stating that the true and fair value concept "has been implemented and/or interpreted in the individual national laws in different ways" and "[ $t]$ his has led to various European perceptions of [the true and fair view], resulting in the possibility that financial statements may provide a [true and fair view] in the perception of one country, whereas the principle is essentially violated in another country."); EUROPEAN BUSINESS LAW: LEGAL AND ECONOMIC ANALYSES ON INTEGRATION AND HARMONIZATION 299-300 (Richard M. Buxbaum et al eds., 1991) (statement of Klaus Hopt) ("[the true and fair view principle] is beautifully incorporated into the German commercial law statute. But... [e]verything is more or less like before. This is true even in the book: the new statutory text is generally interpreted in the light of the old legal situation."). The ECJ, presumably well aware of the far-reaching implications of any broad guideline on how to construe article 2 , has provided very narrow holdings when asked for a preliminary ruling involving its interpretation (the two relevant cases are Case C-234/94, Tomberger v. Gebrüder von der Wettern $\mathrm{GmbH}, 1996$ E.C.R. I3133, and Case C-275-97, DE + ES Bauunternehmung v. Finanzamt Bergheim, 1999 E.C.R. I-5331). Cf. EDWARDS, supra note 23, at 135 ("[In Tomberger, the EC]] couch[ed] its ruling in terms which were both highly specific and extremely cautious."). 
harmonization corporate law tend to prevail, trivializing EC corporate law.

\subsection{The Problem of "Hindsight Bias"}

As Brian Cheffins has argued, "the EU has typically done little more than superimpose a series of measures on domestic regulations already in place." 66 While this may be true with respect to many corporate law issues, ${ }^{67}$ one has to concede that at least in certain policy areas the EC has issued directives before most of the Member States had legislation in place, prompting them to adopt new rules. The most prominent example of a proactive move by the EC is the first directive on insider trading. ${ }^{68}$ Its proposal dates back to 1987, at a time when, among the then existing twelve Member States, only three (France, the United Kingdom, and Denmark) had insider trading prohibitions already in place. ${ }^{69} \mathrm{Re}-$ cently, the European Commission was first in adopting a postEnron policy agenda to respond to U.S. corporate governance reforms and was quickly followed on the same path by many Member States, ${ }^{70}$ some of which, to be sure, have succeeded in converting their reform efforts into law without waiting for the EC's implementation of the Commission's plans. ${ }^{71}$

66 BRIAN R. CHEFFINS, COMPANY LAW: THEORY, STRUCTURE AND OPERATION 448 (1997).

67 Of course, this claim cannot be made with respect to accession countries, especially transition ones, which have in fact had to deeply revise their corporate laws before joining the EU. See Katharina Pistor, Martin Raiser \& Stanislaw Gelfer, Law and Finance in Transition Economies, 8 ECON. TRANSITION 325, 340 (2000) ("European harmonization guidelines have unleashed what some commentators have called a tornado of legislative activities in the countries wishing to join the EU."). This does not imply that EC corporate law has been nontrivial for the ten new accession countries. It only means that these new Member States have had to change their laws in order to introduce, as argued throughout this Section, a set of trivial rules. Cf. id. at 340-41 ("Without a proper understanding of the imported legal concepts [i.e. of the imported harmonized EC rules] ... their role in influencing economic behaviour in the transition may be limited.").

68 Council Directive 89/592, 1989 OJ (L 334) 30.

69 See, e.g., Manning G. Warren III, The Regulation of Insider Trading in the European Community, 48 WASH. \& LEE L. REV. 1037, 1040 (1991) (noting that when the EC's first directive on insider trading was proposed, France, the United Kingdom, and Denmark had proscribed insider trading as a crime, but the other nine countries in the EC had only voluntary schemes or no regulation at all).

70 See Enriques, supra note 26, at 916-25 (providing a detailed account of the reforms made or proposed in France, Germany, and Italy).

71 See id. at 918 (discussing the case of France, which enacted the "Project de loi de sécurité financière " a French equivalent of the Sarbanes-Oxley Act, in July of https://scholarship.law.upenn.edu/jil/vol27/iss1/1 
Thus, EC institutions, at least at times, appear to play a proactive role within the EU, by setting the corporate law reform agenda. However, one should not overestimate the relevance of such proactive moves. In fact, very frequently corporate law reformers around the world work on the same policy issues at the same time. In the second half of the 1980s, this was the case with insider trading: pressure both from capital markets ${ }^{72}$ and from U.S. regulators ${ }^{73}$ prompted a global "rush to prohibit insider trading, or to enforce dormant laws against the practice."74 Arguably, the EC acted as a focal point for such pressures, but Member States were already considering a ban on insider trading at the time ${ }^{75}$ and many of them would have adopted it even in the absence of the directive. Admittedly, this claim is impossible to prove or disprove. But, for instance, Germany's adoption in the 1990s and at the beginning of the new century of a number of laws aiming to promote its financial center by adapting its legislation to international best practices strongly suggests that an insider trading prohibition would have been among those measures, even in the absence of an EC mandate to implement the first insider trading directive. ${ }^{76}$

One may counter that other Member States would never have banned insider trading. This may well be true, but then one should not fail to consider that in some Member States insider trad-

2003).

72 See Harvey L. Pitt \& David B. Hardison, Games Without Frontiers: Trends in the International Response to Insider Trading, 55 Law \& CONTEMP. PROBS., Autumn 1992, at 199, 201-203 (arguing that as markets have become more competitive, the pressure to adopt insider trading laws have increased).

73 See Enrico Colombatto \& Jonathan R. Macey, A Public Choice Model of International Economic Cooperation and the Decline of the Nation State, 18 CARDOZO L. REV. 925, 952 (1996) (explaining that the Securities Exchange Commision exerted pressure on states, such as Japan, Switzerland, and Germany, as well as on the EC itself, to criminalize insider trading).

74 Pitt \& Hardison, supra note 72, at 201.

75 For instance, in 1989 the Italian Parliament was already discussing three bills aiming to criminalize insider trading. Only one of them made a reference to the Directive proposal in its explanatory memorandum. See La disciplina dell' insider trading in Italia [The insider trading regulation in Italy], 1989 RIVISTA DELLE SOCIETÀ 116, 116-23.

76 Cf. Daniel J. Standen, Insider Trading Reforms Sweep Across Germany: Bracing for the Cold Winds of Change, 36 HARV. INT'L L.J. 177, 200-01 (1995) (arguing that the strategic need to promote the German financial center, "Finanzplatz Deutschland," had the greatest impact on the policymakers' choice to ban insider trading in 1994). 
ing prohibitions are so little enforced, 77 that the implementation of the first insider trading directive may have changed virtually nothing for them and their market players. ${ }^{78}$

In sum, policy issues are often on every policymaker's agenda at the same time. In some instances EU institutions are able to adopt directives ahead of Member States, ${ }^{79}$ but this does not mean that such directives significantly change Member States policymakers' course of action.

To conclude, some general features of secondary EC corporate law confirm the hypothesis that such law is trivial: the limited scope of its provisions, which do not cover core company law issues; the problem of under enforcement; the parochial interpretation given to it within Member States; and its timing, since it either

7 See Utpal Bhattacharya \& Hazem Daouk, The World Price of Insider Trading, 57 J. FIN. 75, 81 (2002) (reporting data from 1997 showing that insider trading laws had never been enforced in Austria, Ireland, and Luxembourg). Since 1999, there has been one conviction for insider trading in Austria, E-mail from Martin Gelter, Assistant Professor, Vienna University of Economics and Business Administration, Department of Civil Law, Commercial Law, and Securities Law, to Luca Enriques (Nov. 30, 2004 9:52 CET) (on file with the author), one in Luxembourg, Email from Françoise Thoma, Secretary General, Luxembourg State and Savings Bank, to Luca Enriques (Nov. 30, 2004 7:57 PM CET) (on file with the author), and no conviction yet in Ireland, E-mail from Niamh Moloney, Professor of Capital Markets Law, University of Nottingham School of Law, to Luca Enriques (Dec. 6, 2004 5:01 PM CET) (on file with the author). See also FERRAN, supra note 24, at 33 ("[O]nly nineteen convictions for insider dealing were achieved in Britain, Germany, France, Switzerland and Italy in the five years before 2002, contrasting sharply with the forty-six successful prosecutions achieved in the same period by a single district court in Manhattan").

78 According to a recent study, the existence of a ban on insider trading that is not enforced may actually make things worse for companies in those countries, at least until they enforce insider trading laws for the first time. See Utpal Bhattacharya \& Hazem Daouk, When No Law is Better than a Good Law 6 (January 2005), available at http://ssrn.com/abstract $=558021$ (unpublished manuscript) (finding that the cost of equity rises when a country introduces an insider trading law, but does not enforce it).

79 In other instances, they are not. At the end of the 1990s, for example, corporate governance reform was an issue virtually everywhere, and of course the European Commission also studied whether to issue policy proposals. See Karel Lannoo \& Arman Khachaturyan, Reform of Corporate Governance in the EU, 5 EUR. Bus. ORG. L. REv. 37, 42 (2004) (describing the Commission's attempts to play a more active role in corporate lawmaking during the 1990s). But before the American and European corporate scandals came to light in the first years of the century, the Commission was only able to issue a comparative study of existing corporate governance codes. European Commission, Internal Market Directore General, Comparative Study of Corporate Governance Codes Relevant to the European Union and Its Member States (Jan. 2002), http://europa.eu.int/comm/ internal_market/company/docs/corpgov/corp-gov-codes-rpt-summary_en.pdf. 
covers areas already de facto harmonized from bottom up or regulates issues that were also in Member States policymakers' agenda at the time of their adoption.

\section{ThE TRIVIALITY THESIS 2: NATURE AND CONTENT OF EC CORPORATE LAW RULES}

This Section argues that the provisions laid down by EC corporate law directives and regulations are optional, marketmimicking, unimportant, and/or avoidable, ${ }^{80}$ or, in other words, that with the exceptions outlined in Section 4 they fail to contain any meaningful prohibition, requirement, or enabling rule.

\subsection{Optional Rules}

Optional rules are defined here as those that Member States can freely decide whether or not to implement, or that individual companies may choose whether or not to comply with, through opt-in or opt-out decisions. To be sure, opt-in provisions are not trivial, if they introduce a regime previously unavailable in one of the Member States and if companies in this state do opt into the new regime in significant numbers. ${ }^{81}$ Most EC directives contain optional rules or even allow Member States to choose from a menu of alterna-

80 The classification of trivial rules as optional, market-mimicking, unimportant, or avoidable resembles the classification proposed by Bernard Black, who distinguishes between market-mimicking, avoidable, changeable, and unimportant rules. Bernard S. Black, Is Corporate Law Trivial?: A Political and Economic Analysis, 84 Nw. U. L. REV. 542, 551-61 (1990). "Changeable" rules are not included here for two reasons. First, in general, all rules are changeable, but this does not mean that they are trivial until they are repealed, and it is unreasonable to expect that they will soon be repealed in the absence of regulatory competition. Id. Second, and more specifically, EC rules are less changeable than others, due to the well known petrification of Community law. Once a directive or regulation has been adopted, it is very difficult to amend it, let alone repeal it. BUXBAUM \& HoPT, supra note 45 , at 243.

81 Optional rules may also be nontrivial, if the default rule is "sticky," in other words, if it is costly for firms to opt into the optional regime or to opt out of it. Gérard Hertig \& Joeseph McCahery, Revamping the EU Corporate and Takeover Law Agenda - and Making it a Model for the U.S. 19 (Univ. of Cal., Berkeley, Law \& Econ. Workshop Paper No. 20, 2004), available at http://repositories.cdlib.org/ cgi/viewcontent.cgi?article $=1104 \&$ context=berkeley_law_econ. None of the examples provided in the text of EC corporate law optional rules appear to lead to a sticky outcome, perhaps with the exception of the provision granting preemption rights as it regards to widely held companies with active institutional owners. In fact, such rules usually allow companies to stick to their (or their Member States') previous practices. 
tives. ${ }^{82}$

\subsubsection{Takeovers}

Two prominent examples of optional rules are articles 9 and 11 of the Takeover Directive. ${ }^{83}$ As is well known, the EC succeeded in adopting a directive on takeovers only after the Council and the European Parliament had agreed not to harmonize target companies' defensive tactics, the only politically hot issue in the directive proposal and the one that had led to the European Parliament's rejection of the earlier proposal. 84

The final text still contains two provisions laying down a modified passivity rule. According to the first provision, shareholders' meetings must authorize defensive tactics in advance. ${ }^{85}$ The second is a breakthrough rule trumping restrictions on transfers of shares and providing for a one-share-one-vote rule in the meeting called to authorize defensive tactics and in the first meeting following the bid, provided that, in the latter case, the bidder holds 75 percent of the shares or more following the bid. ${ }^{86}$ Article 12, however, deprives both provisions of practical significance by allowing Member States not to require companies to apply them. ${ }^{87}$ The only condition for this course to be taken is that the Member State allow its companies to opt into the modified passivity and/or breakthrough regimes.

Of course, the modified passivity rule, although optional, might prove not to be completely trivial if, as suggested above, two conditions are met. 88 The first condition is that it allows companies

82 BUXBAUM \& HOPT, supra note 45 , at 234-35.

83 Council Directive 2004/25, arts. 9 \& 11, 2004 O.J. (L 142) 12, 12-13.

84 See, e.g., John W. Cioffi, Restructuring "Germany Inc.": The Politics of Company and Takeover Law Reform in Germany and the European Union, 24 LAW \& POL'Y 355, 384-5 (2002) (discussing the European Parliament's rejection of the draft directive that would have included a requirement that defensive measures be authorized by the general meeting).

85 Council Directive 2004/25, supra note 83, art. 9.

86 Id. art. 11.

87 Id. art. 12.

88 As noted by Magda Bianco \& Bruna Szegö, Le Riforme del Diritto Societario e dell'OPA a Livello Europeo [Amendments of the Corporate Law and of the Takeover Law in Europe], in LA GOVERNANCE DELL'IMPRESA TRA REGOLE ED ETICA 101, 125 (Fabrizio Carotti et al. eds., 2004), the breakthrough rule only applies to companies having made contractual choices such as restricting the transfer of shares or voting rights, so that these companies may already opt into a substantially similar regime by simply abandoning those choices. 
to choose a regime previously unavailable under national law. This appears in fact to be the case in Germany: under German law, public limited companies' statutes may not deviate from the allocation of powers among the different organs as determined by the law. ${ }^{89}$ Therefore, a company statute may not require that frustrating actions, such as a defensive acquisition falling under the scope of the management board's powers according to the law, be authorized by the shareholders' meeting. The second condition is that a nontrivial number of companies from jurisdictions previously precluding such a choice of regimes, and whose control would become contestable if articles 9 and 11 applied, do opt into the directive's new regime.

Provided that a meaningful number of Member States decided to introduce the reciprocity clause in article $12(3)^{90}$ and that a meaningful number of companies did opt into the reciprocity regime, companies planning to act as predators in the EU market for corporate control may have an incentive to opt into articles 9 and 11 in order to have these applied to companies they try to take over. However, the application of articles 9 and 11 should not make much difference with regard to companies controlled by a dominant shareholder (or group of shareholders) and displaying no devices (such as multiple voting shares) that are caught by article $11 .{ }^{91}$ The same is true about the application of article 9 to companies both having dominant shareholders and those displaying devices that are caught by article 11 . In such cases, in fact, dominant shareholders should be able to determine the outcome of

89 See, e.g., KARSTEN SCHMIDT, GESELLSCHAFTSRECHT 770, 869-70 (2002) (describing the mandatory nature of rules allocating powers within the corporation). See also Bianco \& Szego, supra note 88, at 125 (discussing the same with specific reference to defensive tactics).

90 See Council Directive 2004/25, supra note 83, art. 12(3) ("Member States may, under the conditions determined by national law, exempt companies which apply Article 9(2) and (3) and/or Article 11 from applying Article 9(2) and (3) and/or Article 11 if they become the subject of an offer launched by a company which does not apply the same Articles as they do, or by a company controlled, directly or indirectly, by the latter, pursuant to Article 1 of Directive 83/349/EEC."). The content and implications of such a provision are hard to gauge and will very much depend on whether and how Member States will adopt reciprocity. Matteo Gatti, Optionality Arrangements and Reciprocity in the Takeover Directive, in EuROPEAN TAKEOVERS: THE ART OF ACQUISITION 103, 110-12 (Jeremy Grant ed., 2005).

91 Cf. Gatti, supra note 90, at 111 ("[T]he mere fact that a company is subject to the board neutrality rule and/or the [break-through rule] does not automatically make it contestable."). 
shareholders' resolutions on defenses under article 9, the only difference being that, in some countries, granting the power to decide on defenses to the shareholders' meeting might be a legally troublesome formality. ${ }^{92}$ Hence, such companies may opt into article 9 alone in order to facilitate their acquisitions. Much harder to predict is whether companies having both dominant shareholders and devices in place that are caught by article $11^{93}$ would find it convenient to opt into the breakthrough rule in order to facilitate their planned acquisitions. Nor is it easier to predict whether management-controlled companies may find it convenient to adopt the modified passivity rule for the same purpose. For sure, leaving aside the issue of reciprocity, management-controlled companies are unlikely to opt into the shareholder-friendlier regime, unless coalitions of institutional shareholders prompt them to do so.

\subsubsection{Accounting}

The accounting directives leave Member States with plenty of leeway with regard to accounting rules to impose upon their companies. In their current version, the Fourth and Seventh Council Directives ${ }^{94}$ contain, respectively, 45 and 57 opt-in or opt-out provisions, while both also provide for further options for individual companies. Legal scholars agree that this menu of options has "allow[ed] member states to preserve their accounting tradition."95

92 It would be a troublesome formality in countries, such as Germany, where shareholders may easily challenge the validity of shareholders' meetings resolutions in court. See, e.g., Ulrich Noack \& Dirk Zetzsche, Corporate Governance Reform in Germany: The Second Decade, 16 EUR. Bus. L. REV. 1033, 1044-45 (2005) (discussing current reform initiatives aimed at restricting the often abused shareholders' right to challenge the validity of shareholder meeting resolutions in court).

93 Article 11 is, by hypothesis, irrelevant for companies displaying no devices covered by it. Council Directive 2004/25, supra note 83, art. 11.

94 Fourth Council Directive, supra note 31; Seventh Council Directive 83/349, 1983 O.J. (L 193) 1.

95 Werner F. Ebke, Accounting, Auditing and Global Capital Markets, in CORPORATIONS, CAPITAL MARKETS AND THE BUSINESS IN THE LAW: LibER AMICORUM RICHARD M. BUXBAUM 113, 119 (Theodor Baums et al. eds., 2000); see also Eddy Wymeersch, About Techniques of Regulating Companies in the European Union, in REFORMING COMPANY AND TAKEOVER LAW IN EUROPE 145, 166 (Guido Ferrarini et al. eds., 2004) (noting that each Member State's individual implementation of substantive rules coupled with the "options" provided by the directives which are especially prevalent in the field of accounting leads to harmonization that is more apparent than real); FRANK WOOLRIDGE, COMPANY LAW IN THE UNITED KINGDOM AND THE EUROPEAN COMMUNITY: ITS HARMONIZATION AND UNIFICATION 13 (1991) ("[The Fourth Council Directive] is to a large extent a compromise measure, which endeavours to leave much of the law and practice of each Member State intact."). 
However, one should add that, at least in some countries such as Italy and Spain, the directives have significantly upgraded accounting practices. ${ }^{96}$ For instance, before the Seventh Council Directive, only listed companies were required to prepare consolidated annual accounts in Italy, ${ }^{97}$ while no such requirement existed for any company in Spain..$^{98}$

\subsubsection{Legal capital}

Up to a point, even minimum capital and capital maintenance rules in the Second Council Directive can be described as optional. ${ }^{99}$ There is nothing to prevent Member States from imposing a minimum capital as low as that prescribed by the Second Council Directive (25,000 euro), ${ }^{100}$ nor anything to prevent individual companies from fixing a legal capital equal to the minimum and counting further contributions as share premiums. ${ }^{101}$ As a matter of fact,

96 See A. Russo \& F. Siniscalco, The Fourth Directive and Italy, in EEC ACCOUNTING HARMONISATION: IMPLEMENTATION AND IMPACT OF THE FOURTH DIRECTIVE 63, 64-65 (S.J. Gray \& A.G. Coenenberg eds., 1984) (outlining the accounts incorporated in the Fourth Directive but not included in Italian law and noting that the Fourth Directive's distinction between short and long term debtors may contribute to a clearer view of the balance sheet and that the inclusion of "financial fixed assets" and "other loans" are very meaningful additions).

97 See, e.g., Gian Franco CaMPOBASSO, DiritTo COMMERCIALE [COMMERCIAL LAW], 2, DIRITTO DELLE SOCIETA 473 (5th ed. 2002) (reporting that consolidated accounts have become mandatory for all corporations other than smaller ones following implementation of the Seventh Directive).

98 See, e.g., Araceli Mora \& William Rees, The Early Adoption of Consolidated Accounting in Spain, 7 EUR. ACCT. REV. 675, 681 (1998) (noting that there was no obligation to draw consolidated financial accounts in Spain prior to implementation of the Seventh Directive); see also Haller, supra note 32, at 156 ("group accounts... which have been heavily neglected prior to the Seventh Directive in many Member States (e.g. Austria, Belgium, Italy, Greece and Spain) - have increasingly become recognized as a solid basis for investment decisions.").

99 See also Wolfgang Schön, The Future of Legal Capital, 5 EuR. Bus. ORG. L. REV. 429, 436-39 (2004) (describing capital maintenance rules as opt-in provisions); $c f$. Gérard Hertig, Efficient Fostering of EU Regulatory Competition, 2004 SCHWEIZERISCHE ZEITSCHRIFT FÜR WIRTSCHAFTSRECHT [SWISS J. BUS. LAW] 369, 371 (2004) (SWITZ.).

100 Second Council Directive 77/91, supra note 47, art 6. Consider also that the Second Directive only requires that at least one-quarter of the subscribed capital be paid up at the time of incorporation. Id. art. 9 .

101 It is, however, true that most existing public limited liability companies' legal capital is much higher than the Second Council Directive's and even than the Member States' prescribed minimum, due to choices made in the past and possibly prompted by banks. It would be difficult for them to reduce their capital to the statutory minimum, unless, of course, the banks agreed. For banks, it would mean switching from a system in which the law provides a cap on distributions 
the Second Council Directive does not require that the share premium account be treated as share capital or as a non-distributable reserve for capital maintenance purposes.102 To be sure, if net assets fall below 25,000 euros, a company will be unable to make distributions to shareholders. ${ }^{103}$ Since a company may have negative net assets with no lower bound for an indefinite time (at least in theory, unless the national company law has the recapitalize or liquidate rule), ${ }^{104}$ this limitation may seem to be nontrivial. However, even in the absence of the Second Council Directive, often a company in such a situation would still be unable to distribute assets to shareholders due to covenants imposed by sophisticated creditors $^{105}$ so legal capital rules of this kind can also be described

following a company's decision to have a high legal capital to one in which they agree on a cap with each individual corporate borrower. For obvious reasons, they prefer to stick to the current system, which managers and dominant shareholders also like because it allows and even requires them to retain more free cash. See Enriques \& Macey, supra note 60, at 1202 (arguing that the Second Council Directive's legal capital rules help justify dominant shareholders' or managers' decision to reinvest profits). This appears to be a major qualification to the idea that legal capital rules are trivial. See also infra text accompanying notes 196, 205. However, one should consider, first, that most Member States had legal capital rules already in place at the time companies chose to have a high legal capital (so that their choice had nothing to do with the Second Company Law Directive), and second, that the repeal of legal capital rules would not change things significantly for existing companies with a high legal capital. Banks would probably reserve veto power on capital reductions, which managers and controlling shareholders, unless their interests are aligned with outside shareholders', will be willing to accept in order to control a larger pie. Finally, arguing that the overall impact of legal capital rules is trivial (with due qualifications) does not mean that they are justified from an economic point of view. These rules impose costs, however trivial for any individual company, while having no offsetting benefits for creditors or society as a whole. See Enriques \& Macey, supra note 60, at 1185-95 (discussing generally the lack of benefits of the legal capital doctrine).

102 See Reforming Capital: Report of the Interdisciplinary Group on Capital Maintenance, 15 EUR. BUS. L. REV. 919, 939-940 (2004) (noting that as a matter of EC law the share premium account need not be treated as share capital or as an nondistributable reserve).

103 Note that the recent adoption of the International Accounting Standards Board's ("IASB") International Financial Reporting Standards ("IFRS") by the EC and the consequent obligation to treat stock options and pension scheme deficits as expenses, $i d$. at $948-60$, has no impact upon the Second Council Directive rules on distributions as a matter of EC law. In fact, according to Commision Regulation 1606/2002, 2002 O.J. (L 243) 1 (EC), IFRS are only mandatory for consolidated accounts, while restrictions on distributions are related to the annual accounts of individual companies.

104 See infra text accompanying note 263.

105 See, e.g., Clifford W. Smith, Jr. \& Jerold B. Warner, On Financial Contracting: An Analysis of Bond Covenants, 7 J. FIN. ECON. 117, 131-35 (1979) (discussing how https://scholarship.law.upenn.edu/jil/vol27/iss1/1 
as market-mimicking to some degree.

\subsubsection{Preemption rights}

A cornerstone of the Second Council Directive is the shareholders' right (subject to exceptions) to preemption on newly issued shares in article 29. As a matter of fact, this provision boils down to a default rule from which companies may opt out through a resolution at the shareholders' meeting to be taken from five years to five years. The resolution must be taken by at least one of the majorities prescribed in article 40 (two thirds of the shares represented at the meeting or, if a majority of the shares is present, a simple majority of the shares present). This is a protection for qualified minorities that may try to block the meeting's resolution if less than a majority of the shares are represented, but hardly an insurmountable obstacle for most companies, ${ }^{106}$ at least in continental European countries, where ownership is concentrated.107 Further, and even more importantly, Member States may partially opt out of the mandate for preemption rights by choosing not to grant them for issues of shares "which carry a limited right to participate in distributions within the meaning of Article 15 and/or in the company's assets in the event of liquidation." 108

bond covenants restrict the payment of dividends).

$106 \mathrm{Cf}$. DAVIES, supra note 23, at 635 ("[T] he statutory pre-emptive rights can be disapplied [sic] with relative ease and afford an individual equity shareholder precious little assurance that his existing preemptive rights will be preserved unless his shares carry sufficient votes to block the passing of a special resolution.").

107 But see Dirk A. Zetzsche, Explicit and Implicit System of Corporate Control - A Convergence Theory of Shareholder Rights 53-58 (Ctr. for Bus. \& Corp. Law Research Paper Series, Paper No. 0001, 2004), available at http://papers.ssrn.com/ sol3/papers.cfm?abstract_id $=600722$ (suggesting that provisions requiring shareholder approval of certain decisions are especially relevant in countries where the law protects minority shareholders by imposing a broad duty to disclose information prior to a meeting and by granting individual shareholders the right to challenge the validity of shareholder meetings resolutions taken without due disclosure).

As noted in DAVIES, supra note 23 , at $637-38$, in the United Kingdom, institutional investors have agreed upon a strict policy with respect to proposals to issue new shares without offering them to existing shareholders on a preemptive basis, while companies think that preemption rights increase the cost of raising capital.

108 Second Council Directive 77/91, supra note 47, art. 29(2) (emphasis added). The United Kingdom has made use of this option. See EDWARDS, supra note 23, at $85 \mathrm{n} .197$ (limiting "s 89 to 'equity shares' as defined in the Companies Act 1985, s 94").

Published by Penn Law: Legal Scholarship Repository, 2014 


\subsubsection{Authority to bind the company}

A further instance of an optional rule is found in article 9 of the First Council Directive. This article aims to protect third parties by "restrict[ing] to the greatest possible extent the grounds on which obligations entered into in the name of the company are not valid."109 As the Swedish experience illustrates, this article "formally only applies to company organs, i.e., in Swedish law, the board of directors and managing director." 110 What happens in Sweden is that

[I]n everyday business life it is common for major contracts to be concluded by an authorised signatory, and not by the board of directors as such or by the managing director. ... Since an authorised signatory is not a company organ, the old rule still applies, which is the same as in Swedish agency law. The result is that the old doctrine of ultra vires can still be invoked against a third party who acts in culpable bad faith. ${ }^{111}$

In other words, it is common practice in Sweden to opt out of the EC derived rule on companies' authority. ${ }^{112}$

109 First Council Directive 68/151, Preamble, 1967-69 SPEC. ED. 41, 41.

110 Andersson, supra note 27, at 191.

111 Id.

112 See 35 § Aktiebolagslagen [Companies Act] (SFS 1975:1385) (providing the rules governing ultra vires acts under the Swedish Companies Act). One may counter that article 9 is not trivial since it dictates what the default rule is across the EU, thereby reducing the risks associated with the fact that companies can only act through agents, and that it is often difficult, especially in cross-border settings, to find out what the law regulating companies' authority is. This may be true for limits "arising under the statutes or from a decision of the competent organs." First Council Directive, supra note 52, art. 9, para. 2. However, article 9, paragraph 1 itself allows Member States to choose either of two regimes on ultra vires. Cf. Gianluca La Villa, The Validity of Company Undertakings and the Limits of the E.E.C. Harmonization, 3 ANGLO-AM. L. REv. 346, 347 (1974) (arguing that article 9 fails to provide "a unitary principle which completely harmonizes the various legislations of member states" relating to the powers of the company's representatives). Further, the First Council Directive does not cover limits deriving from domestic laws nor does it harmonize rules on corporate agents' conflicts of interest, as the ECJ itself clarified. See Case C-104/96, Cooperatieve Rabobank "Vecht en Plassengebied" BA v. Erik Aarnoud Minderhoud, 1997 E.C.R. I-7211 (declining to look to the First Directive to decide a case of conflict of interest and stating that it does not apply). 


\subsubsection{European Company Statute}

Another set of totally optional rules is the European Company Statute, 113 which introduced an additional legal form, regulated partly by the statute itself and partly by national corporate laws. The impact of the statute might prove to be nontrivial if companies start using the new form as a means to implement cross-border mergers or to reincorporate in another jurisdiction. ${ }^{114}$ It is too early to predict whether this will be the case.115 For certain, however, there are still tax obstacles that may make it practically impossible to use the new legal form for cross-border mergers or reincorporations. ${ }^{116}$ According to most observers, the legal regime of the European company itself is too complex and too rigid to make the new legal form attractive. ${ }^{117}$

\subsubsection{Mutual recognition: the case of securities offerings}

Finally, rules on mutual recognition and more generally aiming

113 See Council Regulation 2157/2001, 2001 O.J. (L 294) 1 (EC) (laying out current regulations for European limited liability companies and pointing out that aside from the laws of a particular Member State there are no rules required to be enacted for this type of company); see also Council Directive 2001/86/EC, O.J. (L 294) 22 (discussing what Member States should do in the field of employee involvement in limited liability companies, but making no concrete rules that must be followed).

114 See Luca Enriques, Silence Is Golden: The European Company As a Catalyst for Company Law Arbitrage, 4 J. CORP. L. STUD. 77, 79-80 (2004) (discussing the Societas Europaea ("SE") legal form as a vehicle for company law arbitrage and suggesting that one of the possible reasons why European businesses might want to opt for the SE legal form is because it facilitates cross-border joint ventures and mergers).

115 The European Company Statute was entered into force on October 8, 2004, Regulation 2001/2157, 2001 O.J. (L 294), but only five Member States had already taken the necessary measures to allow European Companies to be founded on their territory. Press Release, European Commission, Company Law: European Company Statute in Force, But National Delays Stop Companies Using It (Oct. 8, 2004), available at http:/ / europa.eu.int/rapid/pressReleasesAction.do?reference= IP/04/1195\&format=HTML\&aged=0\&language=en\&guiLanguage=en .

116 See Joseph A. McCahery \& Eric P.M. Vermeulen, Does the European Company Prevent the 'Delaware Effect'? 20 (TILEC Discussion Paper No. 2005-010, 2005), available at http://papers.ssrn.com/sol3/papers.cfm?abstract_id=693421 ("[T]he failure of the European Statute to address the problem of taxation will clearly undermine the number of firms incorporating as European companies.").

117 See, e.g., Evanghélos Pérakis, SE: Une société pour quelles entreprises? [European company: A society for which enterprises?], in LA SOCIETE EUROPEENNE. ORganisation JuRIDIQUE ET FisCale, INTERETS, PERSPECTIVES [THE EUROPEAN SOCIETY. Judicial AND FisCAL ORGANIZATION, INTERESTS, PERSPECTIVES] 227, 229-31 (Klaus J. Hopt et al. eds., 2003).

Published by Penn Law: Legal Scholarship Repository, 2014 
to facilitate cross-border transactions, such as cross-border offerings and listings, are enabling rules; i.e., they are optional and only apply when companies want to take advantage of them. Therefore, even these rules can be evaluated as trivial or not, depending on whether companies across the EU indeed take advantage of the newly available opportunities.

From this point of view, the new Prospectus Directive ${ }^{118}$ is seen by many "as a big step forward as compared to the previous measures in place."119 The previous regime was a failure, since cross-border public offerings were extremely rare. ${ }^{120}$

It is of course too early to tell whether the new regime will work, that is, if the number of cross-border public offerings will significantly increase. ${ }^{121}$ However, practitioners have already identified some features in the Prospectus Directive that could determine its failure: in short, it is suggested that, while it will be possible to make a cross-border public offering relying on a prospectus in English and, if the host or the home Member State so requires, on a translation in the local language of the summary only, "the summary is required to contain a wording that it should be read as an introduction to the prospectus and any decision to invest in the securities should be based on consideration of the prospectus

118 Council Directive 2003/71, 2003 O.J. (L 345) 64 (EC) [hereinafter Prospectus Directive].

119 Lannoo, supra note 44 , at 346.

120 See Howell E. Jackson \& Eric J. Pan, Regulatory Competition in International Securities Markets: Evidence from Europe in 1999-Part I, 56 Bus. LAW. 653, 680 (2001) (reporting that few issuers were taking advantage of mutual recognition provisions under the prior securities offerings directive); Lannoo, supra note 44 , at 340 (stating that "[under the previous regime,] the offering of equities on a panEuropean basis was severely hampered"); MOLONEY, supra note 41, at 140, 209-10 (describing the obstacles faced by issuers willing to make a cross-border offering under the previous regime).

The directives on listing conditions and particulars, Council Directive 80/390, supra note 41, and Council Directive 82/121, 1982 O.J. (L 48) 26 (EC), are also commonly held to have been ineffective with respect to their purpose of facilitating multiple listings. And, in any event, they have become obsolete following market and technological developments. See Guido Ferrarini, The European Regulation of Stock Exchanges: New Perspectives, 36 COMMON MKT. L. REv. 569, 577 (1999) (discussing specifically Council Directive 82/121 and new initiatives in European stock exchanges regulation).

121 The new regime has gone into force after July 1, 2005. Prospectus Directive, supra note 118, art. 29. But see, FERRAN, supra note 24, at 201 (reporting that "informed market opinion [according to which] retail equity offerings make use of the passport are likely to remain rare").

https://scholarship.law.upenn.edu/jil/vo|27/iss1/1 
as a whole by the investor.'"122 The problem is that it is impossible for an investor who does not speak English to base her decision on consideration of the prospectus as a whole. Further, the summary must have a maximum length, so that it will be impossible to incorporate "a 10 to 15 page section on risk factors."123 Putting two and two together, the risk of civil or criminal liability for publishing a misleading summary ${ }^{124}$ might lead issuers either to translate the whole prospectus or to keep marketing their securities in their domestic market only.125 In other words, the practical outcome might be the same as under the previous regime.

\subsection{Market-Mimicking Rules}

Market-mimicking rules are rules that most private parties would adopt even in the absence of statutory provisions imposing them. As Bernard Black acknowledges, it is hard to prove that a rule is market-mimicking: "The force of the arguments for why a particular rule is market mimicking will depend on analogies, on the background and prior beliefs of the reader, on guesses about transaction costs, and on the force of alternative arguments." 126 As examples of market-mimicking rules, Black cites those requiring approval by a majority of shareholders of major corporate changes, such as mergers and liquidations. Requiring a shareholders' vote on mergers and divisions, as articles 7 and 5 of the Third and Sixth Council Directives ${ }^{127}$ respectively do, can reasonably be categorized as market-mimicking. ${ }^{128}$

Rules granting creditors the right to obtain security for their claims or adequate safeguards in case certain transactions are un-

122 Jim Bartos \& Michael Lippert, Why Europe's New Prospectus Regime May Fail, 22 INT'L FIN. L. REV. 18 (2003).

123 Id. at 19.

124 Prospectus Directive, supra note 118 , art. 6, para. 2.

125 Bartos \& Lippert, supra note 122, at 19. Bartos and Lippert also doubt whether another enabling feature of the Prospectus Directive, incorporation by reference, will work. According to the two authors, in the absence of an integrated system of disclosure such as the one in place in the United States, it will not. Id.

126 Black, supra note 80 , at 552 .

127 Third Council Directive 78/855, 1978 O.J. (L 295) 36; Sixth Council Directive $82 / 891,1982$ O.J. (L 378) 47.

128 See infra text accompanying note 181. 
dertaken, such as reductions of capital, mergers or divisions, ${ }^{129}$ are in part market-mimicking and in part unimportant. They are (timidly) market-mimicking with regard to sophisticated creditors, who normally reserve the far more effective right to veto such transactions (usually in broader and more detailed terms) or insert an acceleration clause applying if these transactions are entered into. ${ }^{130}$ And they are unimportant with regard to other creditors, as explained below. 131

Arguably, the fact that a rule is present in all of the U.S. states' corporation codes is evidence of its market-mimicking character. In fact, although today in the United States the market for corporate charters is not particularly active, ${ }^{132}$ it has been at least in the past, leading most states to converge on a very limited set of rules. Those surviving in each U.S. jurisdiction are thus, intuitively, rules that very few corporations would not choose. William Carney has found that thirteen EC corporate law provisions are adopted in all fifty U.S. states. ${ }^{133}$ Assuming that what is market-mimicking in the

129 See Second Council Directive 77/91, supra note 47, art. 32 (addressing these issues); Third Council Directive, supra note 127, art. 13 (requiring that the Member States have a system in place to protect interests); Sixth Council Directive, supra note 127, art. 12 (mandating security of claims).

130 Smith \& Warner, supra note 105, at 128-36.

131 See infra text accompanying notes 143-145.

132 See Marcel Kahan \& Ehud Kamar, The Myth of State Competition in Corporate Law, 55 STAN. L. REV. 679 (2002) (arguing against the conventional wisdom that states compete for incorporations); Lucian A. Bebchuk \& Assaf Hamdani, Vigorous Race or Leisurely Walk: Reconsidering the Competition over Corporate Charters, 112 YALE L.J. 553 (2002) (arguing that there is currently little regulatory competition going on in the United States). But see Romano, supra note 4, at 12-25 (criticizing the view that there is currently no regulatory competition in the corporate law area).

133 For a table showing which thirteen EC provisions have been adopted by all U.S. states see William J. Carney, The Political Economy of Competition for Corporate Charters, 26 J. LEGAL STUD. 303, 320 (1997). The thirteen provisions are those requiring

[p]ublication of articles of constitution and amendments; . . . [p]ublication of identity of official agent; ... [p]ublication of winding up of company; ... [p]ublication of any declaration of nullity by the courts; and those providing that ... [c]ompletion of formalities of incorporation is a bar to personal liability of agents; ... [that] [1]imits on powers of organs (governing bodies) may not be relied on against third parties even if disclosed; . . . [that] [n] ames of companies shall be distinctive; . . . [that the] [a]rticles of incorporation must identify [the] [r]egistered office .. and [i]dentity of the incorporators; ... [that] [i]f reduction of subscribed capital by compulsory withdrawal of shares is permitted, it must be authorized in the articles of incorporation before the shares are issued, and 
United States is also in the EU, these thirteen provisions can be categorized as such. ${ }^{134}$

\subsection{Unimportant Rules}

Black defines "unimportant rules" as those that "can be complied with at nominal cost, or involve situations that almost never occur." 135 Rules granting rights that will almost never be exercised also qualify as such.

Among rules that can be complied with at nominal (or at least negligible) cost is article 17 of the Second Council Directive ${ }^{136}$, according to which, when a company suffers "a serious loss of the subscribed capital, a general meeting of shareholders must be called within the period laid down by the laws of the Member States, to consider whether the company should be wound up or any other measures taken." 137 Nothing appears to prevent Member States from requiring that this discussion take place at the next annual meeting at the latest, so that companies will not even have to incur the costs of calling an extraordinary meeting for the purpose.

Similarly, the cost of disclosing well-specified facts or documents such as the fact that a company has only one shareholder, 138 the articles of constitution and its amendments, ${ }^{139}$ or the identity of the persons authorized to represent the company ${ }^{140}$ will normally be trivial both in monetary terms and with regard to some hypothetical interest in keeping those facts secret.

Finally, the provision in the Twelfth Council Directive, that contracts between the sole owner and the corporation "shall be re-

must be approved by the shareholders; ... [that the] [r]ights and obligations of redeemable shares must be specified in articles of incorporation before issuance; ... . [that] [b]oard of directors must approve and publish an agreement and plan of merger; ... [that] [n]otice of the merger must be published; ... [ [and that] [ $t$ ] he effect of a merger is to transfer all assets and liabilities to the surviving company.

William J. Carney, Appendix A, Adoption or Rejection of EC Company Law Directives in U.S. (unpublished manuscript, on file with the author).

134 Many of them also appear to be unimportant. Cf. supra note 132.

135 Black, supra note 80, at 560 .

136 Second Council Directive 77/91, supra note 47, art. 17.

137 Id.

138 Twelfth Council Directive 89/667, 1989 O.J. (L 395) 40 (EC), art. 3.

139 First Council Directive, supra note 52, art. 2, para. 1(a).

140 Id. para. $1(\mathrm{~d})$.

Published by Penn Law: Legal Scholarship Repository, 2014 
corded in minutes or drawn up in writing" 141 can also be complied with at nominal cost.

Rules that involve situations that almost never occur include provisions on the nullity of companies. ${ }^{142}$ In Vanessa Edwards's words, "[a] declaration of nullity was a rare occurrence even in those original Member States which recognized the concept, so that these provisions are relatively unimportant." 143

Among rules granting rights that will almost never be exercised are those entitling unsophisticated creditors to obtain security for their claims or adequate safeguards if certain transactions are undertaken, such as reductions of capital, mergers or divisions. ${ }^{144}$ In fact, either such creditors have bargaining power vis-àvis the company or they lack it. If they have bargaining power, but failed to contract for such protections at the outset, possibly because they are unsophisticated, they will be able to protect themselves against the negative consequences of such transactions without the need for a right to obtain those safeguards. If they have no bargaining power, they will be de facto unable to exercise their right, because the company would otherwise retaliate against them. ${ }^{145}$ And in any event, should a creditor in fact exercise the right to obtain security or an adequate safeguard, the instances in which the resulting cost for the companies involved will be such that the transaction will not go through will be so rare as to make this hypothesis, again, trivial.

\subsection{Avoidable Rules}

Avoidable rules are, in Black's terminology, those that can "be avoided through proper planning." 146 In our setting, the planning can take place at the company level, at the national level, or at both: at the company level, when it is private parties who carefully design transactions so as to avoid the application of a given rule; at

141 Twelfth Council Directive, supra note 138, art. 5, para. 1.

142 Id. § III.

143 EDWARDS, supra note 23 , at 46.

144 See infra text accompanying note 181.

145 Cf. Enriques \& Macey, supra note 60, at 1191 (discussing the bargaining power of creditors with regard to reductions of capital). Note that such provisions do not require that the company obtain creditors' consent to execute certain transactions. They require creditors to activate in order to obtain protection, thus making it less plausible that a bargaining problem connected with an endowment effect will arise. 
the national level, when the planning is at the implementation stage as the result of choices made, whether implicitly or explicitly, by policymakers transposing the EC rules.

To be sure, proper planning at the company level can be costly: as Black acknowledges, "[t]he greater the costs of avoidance, relative to a rule's importance, the less avoidable the rule. ... At some point, the cost of avoiding a rule is large enough so that we can't call the rule trivial." 147

As a matter of fact, avoidance costs may be high, especially in light of the legal advice which is normally necessary in the process. Since the costs of avoidance have a strong fixed component, avoidable rules may therefore prove to be nontrivial for smaller businesses, as conceded also in Section IV. ${ }^{148}$

\subsubsection{Capital formation}

An example of rules avoidable at the company level can be found in article 11 of the Second Council Directive, according to which a special procedure has to be followed in order for a company to acquire any asset belonging to one of the company's founders for consideration of more than one-tenth of the company's subscribed capital within two years of incorporation. This provision is easily avoided by starting a business by acquiring an existing, possibly dormant, company incorporated more than two years before, 149 or "by entering into one of the many kinds of ... transactions that Article 11 of the Second Council Directive does not cover." 150 True, there is the risk that Member States' laws will label such transactions as indirectly falling under the scope of the national provision implementing the Directive. ${ }^{151}$ But it is far from certain that this $\mathrm{w}$ be the case, depending also on the care the company and its shareholders have taken in planning the transaction. And, more to the point, this treatment of evasive transactions would be an application of national laws and local judges' activ-

147 Id. at 557.

148 See infra text accompanying notes 198, 205.

149 For a discussion of the various ways by which article 11 can be circumvented, see Marco S. Spolidoro, Gli Acquisti Pericolosi [The Dangerous Purchases], in Trattato delle SOCIetÀ PER AzIONI 679, 724-25 (Giovanni E. Colombo \& Giuseppe B. Portale eds., 2004).

150 Enriques \& Macey, supra note 60, at 1186.

151 See Spolidoro, supra note 149 , at 725-26.

Published by Penn Law: Legal Scholarship Repository, 2014 
ism, not of EC corporate law. ${ }^{152}$

Similarly, the prohibition against the issue of stock in exchange for "an undertaking to perform work or supply services" 153 does not impinge upon the validity of a contract by which the company reserves the right to pay workers' salaries or advisers' fees in shares. Once the work or service has been performed, the workers or the advisers will have a credit with the company. Pursuant to their previous agreement, the company will issue shares as payment for the services. Instead of contributing new money to the company, the workers or advisers will simply offset their debt to the company for the payment of their shares with the company's liquid and due debt for the performed work or services. 154 Such an arrangement would solve any cash constraint by start-up companies. Further, suppose there are two parties, a financier and an entrepreneur, who are willing to form a company in which the former will hold forty-nine percent and the latter fifty-one percent, and that the entrepreneur has no assets that can be validly contributed to the company according to the Directive. Leaving tax issues aside, nothing prevents the financier from paying up the entrepreneur's capital in her stead. ${ }^{155}$ Once the company is formed the entrepreneur may enter, as the case may be, an employment relationship of some kind with the company. ${ }^{156}$

\subsubsection{Share buy-backs}

Proper planning will also allow avoidance of the Second Coun-

152 See Case C-83/91, Meilicke v. ADV/ORGA, Opinion by Advocate General Tesauro 1992 E.C.R. I-4871, para. 21 ("[E]ach legal system is entitled to use its own general legal provisions ... to penalize operations in which avoidance, rather than being irrebuttably presumed - that, essentially, being the effect of Article 11 -is proved by other means. ..."). Member States in fact differ as to their reactions against evasive transactions. Cf. Halbhuber, supra note 27, at $1406 \mathrm{n} .109$ (reporting the different treatment of evasion of rules on contributions in kind in Germany and in England).

153 Second Council Directive 77/91, supra note 47, art. 7.

154 Cf. Meilicke v. ADV/ORGA, paras. 15-16 (stating that article 10 does not apply to contributions by waiver of a liquid and due debt).

155 See Marco S. Spolidoro, Conferimenti e Strumenti Partecipativi nella Riforma delle Società di Capitali, in DiRITTO DELla BANCA E DEL MERCATO FINANZIARIO [CONTRIBUTIONS AND STAKES IN THE AMENDMENT OF CORPORATIONS LAW] 205, 209 (2003) (regarding Italian law specifically).

156 Article 11 does not apply to employment contracts, because it refers to "asset[s]" (or "élément[s] d'actif" in the French version), while credit for future work is not an "asset" as accountants use the term. Second Council Directive 77/91, supra note 47 , art. 11 . 
cil Directive provision capping the number of own shares a company may hold at any given moment at 10 percent.157 In fact, a company having reached that cap may acquire further shares after reducing the share capital and cancelling the treasury shares in excess. This will of course be cumbersome, because a shareholder meeting will have to be convened to decide on this. But it is unlikely to deter a motivated company. ${ }^{158}$

\subsubsection{Financial assistance}

Article 23 of the Second Council Directive is perhaps the most telling example of an avoidable EC company law rule. This sweeping prohibition against firms providing financial assistance to those acquiring their shares is said to render leveraged buyouts illegal. ${ }^{159}$

The sheer volume of private equity buyouts in Europe indicates that the hindering effect of article 23 cannot be as great as is often contended. In 2003, a total of 945 private equity buyouts were completed-24\% fewer than in 2002-for a total value of 61,691 million euros, eight billion less than the previous year, 160 while in 2004 "[a] record $\$ 40$ billion of loans for leveraged buyouts have been arranged in Europe... compared with $\$ 29$ billion for ... 2003."161 In the last few years, the European buyout market has grown even bigger than that of the United States. Since 2001 buyout activity in Europe has been $70 \%$ greater than in the United States in terms of announced deal value.162

In the face of article 23, how can this be? First, some Member States, and notably the United Kingdom, have introduced exemptions. ${ }^{163}$ Second, in all Member States "intricate... evasion tech-

157 Id. art. 19(1)(c)

158 The provisions granting creditors the right to obtain adequate security in the process will be either market-mimicking or unimportant, having therefore no chilling effect either. See supra text accompanying notes 128-131, 143.

159 See, e.g., Reforming Capital, supra note 102, at 945 ("The prohibition [on financial assistance] ... remains for public companies a major and costly impediment to wholly legitimate and desirable commercial transactions, for example leveraged buy-outs.").

160 INITIATIVE EUROPE, INITIATIVE EUROPE BAROMETER Q4 20034 (2003), at http://www.initiative-europe.com/press/downloads/Q42003.pdf.

161 Record Debts in European Buyouts Spur 'Credit Bubble' Concerns, BLOOMBERG.COM (Dec. 29, 2004), http://www.bloomberg.com/apps/news?pid= $10000085 \&$ sid $=$ arzvgEO2dYs4\&refer=europe\#.

162 See Peter Smith, Buy-Out Groups on the Spree in Europe, FIN. TIMES (London), Aug. 2, 2004, at 18 (reporting data collected by JPMorgan).

163 See, e.g., Eilís Ferran, Company LAW AND CoRporate Finance 391-92 
niques have been invented by smart lawyers," 164 which national courts, for better or for worse, have usually judged to be in line with the prohibition on financial assistance. ${ }^{165}$

\subsubsection{Major holdings}

Avoidable rules can be found in securities regulation as well. First, there are certainly ways around the obligation to disclose major holdings as required once by Directive 88/627166 and now by Directive 2001/34. ${ }^{167}$ One has been reported by Marco Becht and Ekkehart Böhmer. ${ }^{168}$ When a stake is held by a company, the disclosure obligation applies to owners exercising control over it.

(1999) (describing the exemptions based on the 1985 Companies Act's purpose of financial assistance).

164 Wymeersch, supra note 95, at 177.

165 Eddy Wymeersch, Article 23 of the Second Company Law Directive: The Prohibition on Financial Assistance to Acquire Shares of the Company, in FESTSCHRIFT FUR UlRICH DROBNIG [COMMEMORATIVE PAPER FOR ULRICH DROBNIG] 725, 735, 738-39 (Jurgen Basedow et al. eds., 1998) (reporting arguments developed in various Member States to construe the prohibition restrictively); see also Niccolò A. Bruno, Il Leveraged Buy Out nella Casistica Giurisprudenziale [Leveraged Buy Out in Court Cases], 2002/I BANCA BORSA TITOLI DI CREDITO [BANK, STOCK EXCHANGE AND NOTES] 806,814 (finding that no Italian court has ever declared a leveraged buy-out illegal). A recent decision by the English Court of Appeal, Chaston v. SWP Group plc, [2002] EWCA (Civ) 1999, [2003] 1 B.C.L.C. 675, however, failed to accommodate a restrictive interpretation of the financial assistance prohibition. As Eilis Ferran notes, this decision has reminded corporate finance practitioners that they must:

continue to operate on the basis that financial assistance is a pervasive and serious problem which must be grappled with in order to find ways around it that have not been undermined by the case law. It seems inevitable that the processes involved in avoiding financial assistance problems will continue to involve significant costs. There is anecdotal evidence that many law firms have already consulted leading company law barristers for advice on the implications of Chaston and it seems reasonable to assume that this will be a continuing source of revenue for a few specialists. The amounts involved are necessarily a matter of speculation, but it is safe to say that the advice of leading members of the corporate Bar certainly does not come cheap.

Eilís Ferran, Corporate Transactions and Financial Assistance: Shifting Policy Perceptions but Static Law, 63 CAMBRIDGE L.J. 225, 226 (2004).

166 Council Directive 88/627, supra note 41.

167 Council Directive 2001/34, 2001 O.J. (L 184) 1.

168 See Marco Becht \& Ekkehart Böhmer, Ownership and Voting Power in Germany, in THE CONTROL OF CORPORATE EUROPE 128, 151 n.7 (Fabrizio Barca \& Marco Becht eds., 2001) (stating that "voting blocks in holding companies do not have to be disclosed unless one shareholder has majority control"). 
Since the definition of control does not include joint control, 169 in Germany "shares held by unlisted firms with two $50 \%$-owners are never attributed beyond the level of the unlisted firm, because neither of the owners is deemed to be controlling." 170

\subsubsection{Securities offerings}

A further example of avoidable rules can be found in the prospectus regime in place prior to the adoption of the Prospectus Directive. As Howell Jackson and Eric Pan report, 171 it was common practice for issuers to offer their securities in other Member States to professionals only, relying upon the exemption for such offerings in the relevant directive. ${ }^{172}$ The professionals would then resell the securities to retail investors. ${ }^{173}$ This was possible because neither Directive 89/298 nor the securities laws of at least some Member States ${ }^{174}$ imposed resale restrictions similar to the Securities \& Exchange Commission's Rule 144.175

The new Prospectus Directive would appear to require a prospectus for any resale which may fall under the broad definition of "offer to the public" provided for in article 2(1)(d). ${ }^{176}$ However, it is expected that the United Kingdom (and possibly other Member States) will carve-out an exception in the definition of "offer to the public" for communications in connection with screen trading on, inter alia, multilateral trading facilities. ${ }^{177}$ If this occurs, it may

169 Council Directive 2001/34, supra note 167, art. 87.

170 Id. This will hold true also under Council Directive 2004/109 of the European Parliament and of the Council of 15 December 2004 on the harmonization of transparency requirements in relation to information about issuers whose securities are admitted to trading on a regulated market. This Directive will amend Directive 2001/34/EC, whose provisions on major holdings will come into force on January 20, 2007. Council Directive 2004/109, art. 2(1)(f), 9, 2004 O.J. (L 390) 38.

171 Jackson \& Pan, supra note 120, at 681-82.

172 Council Directive 89/298, para. 1, 1989 O.J. (L 124) 8.

173 Jackson \& Pan, supra note 120 , at 688 . See generally MOLONEY, supra note 41 , at 68 (observing that "the Securities Directives contain substantial escape opportunities for Member States from their harmonizing effects in the form of a network of exemptions, derogations, and generally worded obligations").

174 See, e.g., Renzo Costi \& LuCa Enriques, Il Mercato Mobiliare [The SECURITIES MARKET] 59-60 (2004) (noting that Italian securities laws impose no resale restrictions).

17517 C.F.R. $\$ 230.144$ (2000).

176 Council Directive 2003/71, art. 3(2), 2003 O.J. (L 345) 71.

177 HM Treasury \& FSA, UK IMPLEMENTATION OF THE PROSPECTUS DIRECTIVE 2003/71/EC. A CONSUlTATION DOCUMENT at 22 (Oct. 2004), available at http:// www.hm-treasury.gov.uk/media/DFE/27/DFE27339-BCDC-D4B3-16FD311B308 
prove easy for qualified investors to resell securities to retail investors through these trading venues without a prospectus. Further, each resale will be regarded as a separate offer, ${ }^{178}$ so that "a resale addressed to fewer than one hundred persons, whatever their status, would fall outside the prospectus requirement for resales."179

To be sure, the new Prospectus Directive is also a maximum harmonization measure. As such, it will definitely have an impact upon any offer to the public by exclusively identifying what will have to be disclosed in the prospectus. However, as Eilís Ferran has suggested, Member States may "side step the maximum harmonization effect of the Prospectus Directive by recasting disclosure requirements that are outside the Directive in the form of substantive criteria that must be satisfied by issuers seeking admission to trading on a regulated market." 180

\subsubsection{Mergers and divisions}

Good examples of secondary EC corporate law rules that can be avoided by efforts at the national level are those in the Third and Sixth Council Directives on mergers and divisions. The United Kingdom has, in fact, implemented these directives through provisions that cover a very limited set of transactions, leaving parties free to achieve the same results as those normally sought through mergers or divisions, by choosing transactional structures not covered by the directives. ${ }^{181}$ The fact that at least one Member State was able to reduce the impact of these directives practically to nothing, and apparently without breaching them, is evidence that they have no bite.

\subsubsection{Mandatory bids}

Some rules are avoidable thanks to planning both by the Member State at the implementation stage and by private parties. The best example of this kind of rule is perhaps the provision requiring

ABF54.pdf.

178 Council Directive 2003/71, supra note 176, art. 3(2).

179 FERRAN, supra note 24, at 201 n.257. See also id., at 200-01 ("Preventing seepage from wholesale to retail markets through resales of securities that were offered originally on an exempt basis remains an issue that EU policy-makers appear disinclined to address vigorously.").

$180 \mathrm{Id}$. at 145.

181 DAVIES, supra note 23, at 799-800; EDWARDS, supra note 23, at 83, 85. 
Member States to have a mandatory bid rule in place. ${ }^{182}$ This provision allows the measure to be implemented through easily avoidable rules. First, according to article 4, paragraph 5 of the Takeover Directive, "[p]rovided that the general principles set out in Article 3(1) are respected, Member States may ... grant derogations" from the Directive's rules, including the mandatory bid rule, "in certain types of cases determined at national level." They may also grant their supervisory authority "the power to waive national rules." 183 Second, the Directive does not identify the threshold for the mandatory bid obligation. ${ }^{184}$ It only states that the shares held have to confer on the acquirer "the control of that company." 185 Nothing appears to prevent Member States from fixing the threshold, at, say, fifty percent plus one share, making it easy for control to change hands without triggering the requirement. Further, as I have argued elsewhere, the few, patchy provisions on the mandatory bids contained in article 5 "leave plenty of room for more or less ingenious ways to avoid the mandatory bid requirement, depending, of course, on how national implementing rules are drafted and enforced." 186

\subsection{Conclusions}

This Section and the previous one have provided arguments in favor of the triviality thesis. They have shown that many EC company law rules are trivial and have very little impact upon EC companies' governance and management. They do not cover core areas such as fiduciary duties and shareholder remedies, and they are under-enforced and normally construed so as to be compatible

182 Council Directive 2004/25, supra note 83, art. 5.

183 As I have noted elsewhere:

[U]njustified or over-ample use of this power may constitute a breach of Article 3(1)(a) (protection of minority shareholders in case of control transfer), unless of course some other equivalent form of protection is provided. In any event, the grey area in which a reasoned decision may be judged to be consistent with the directive is broad enough to leave Member State and local supervisory authorities considerable influence in the administration of the national mandatory bid regime.

Luca Enriques, The Mandatory Bid Rule in the Proposed EC Takeover Directive: Harmonization as Rent-Seeking?, in REFORMING COMPANY AND TAKEOVER LAW IN EUROPE, supra note 95 , at $767,774$.

184 Council Directive 2004/25, supra note 83, art. 5, para. 1.

185 Id. para. 3.

186 Enriques, supra note 183 , at 776.

Published by Penn Law: Legal Scholarship Repository, 2014 
with pre-existing national rules and practices. Finally, most EC corporate law can be categorized as optional, market-mimicking, unimportant, or avoidable. In other words, there is (almost) ${ }^{187}$ nothing nontrivial that EC corporate law requires, forbids, or enables.

\section{SOME QUALIFICATIONS TO THE TRIVIALITY THESIS AND ONE POSSIBLE OBJECTION}

It would be an overstatement to conclude that secondary EC corporate law is trivial without any qualification. This Section provides the necessary qualifications to the triviality thesis and counters a possible objection to it, specifically that the same kind of analysis would justify the conclusion that even EU national corporate laws are trivial.

\subsection{Qualifications to the Triviality Thesis}

A few qualifications have to be made to the triviality thesis. First, a few provisions or sets of rules are nontrivial. Second, EC corporate law has increased the regulatory burden of corporate laws across the EU, correspondingly securing more benefits for certain interest groups. Third, EC corporate law plays a role in the evolution of corporate law within the EU, prompting preemptive changes in national corporate laws, creating the scope for excessive regulation, acting as a curb on experimentation, and making it somewhat less likely that a European Delaware will emerge. Finally, its production has become an industry itself, employing many EC and national functionaries and lobbyists, and creating occasions for rent extraction by politicians.

\subsubsection{The exceptions}

The analysis in the previous Sections has not provided an exhaustive list of the existing secondary EC company law provisions in order to show that each of them is trivial. Instead, it has provided some general reasons why secondary EC company law is trivial and categorized most of its provisions as optional, marketmimicking, unimportant, or avoidable. However, one has to concede that a few specific rules or sets of rules have indeed had, or can be predicted to have, an impact on companies and their behav- 
ior.

First, we can cite the Takeover Directive provision granting a successful bidder the right to purchase shares from minority shareholders ${ }^{188}$ : unless Member States find ways to make this right de facto impossible to exercise, for example, by making it extremely easy for minority shareholders to challenge the fairness of the squeeze-out price or block the squeeze-out procedure, one can predict that highly successful bidders will often exercise their squeeze-out rights. One can also mention the Eighth Council Directive's ${ }^{189}$ provisions defining the professional qualifications of persons in charge of the auditing of a company's accounts (as imposed by the Fourth and Seventh Council Directives), 190 because in comparison with the requirements until then in force in at least some of the Member States (e.g., Italy), the Directive's requirements involved an upgrade of the professional qualifications requested. ${ }^{191}$

Further, despite the optional character of most of the Fourth and Seventh Council Directives' provisions and the tendency to construe them according to local practices and traditions, the accounting directives have had, and, in the case of the International Accounting Standards ("IAS") Regulation, are already having, a significant impact on companies. ${ }^{192}$ Of course it remains to be seen whether and how uniformly the international accounting standards will be enforced. ${ }^{193}$

Finally, one may argue that the mandatory disclosure rules in securities directives have also implied an upgrade of national regulations. However, the enforcement issue in this area may be so se-

188 Council Directive 2004/25, supra note 83, art. 15. The corresponding sellout right provision, article 16, appears to be at least as easily avoidable as the provision on mandatory bids since it presupposes a voluntary or mandatory bid made to all the holders of the offeree company. See supra text accompanying notes 183-185.

189 Eighth Council Directive 84/253, 1984 O.J. (L 126) 20.

190 Fourth Council Directive 78/660, supra note 31, art. 51; Seventh Council Directive $83 / 349$, supra note 94 , art. 37.

191 Of course, the Eighth Council Directive contained grandfathering provisions for auditors in practice at the time of implementation and with lower qualifications than those required by the Directive itself. See Eighth Council Directive, supra note 189 , arts. 12-18.

192 See Haller, supra note 32, at 159 (describing the impact of the accounting directives as "enormous").

193 See supra text accompanying note 44. 
rious as to make such rules trivial. ${ }^{194}$

Recent developments in securities law, with the EC's new approach to legislation and enforcement of securities laws, could increase the impact of EU action, although it is still too early to say whether this will indeed be the case. 195

\subsubsection{Impact on the cost of doing business and on professionals' fees}

As argued in Section III, most corporate law rules are trivial in the sense that there is almost nothing meaningful that EC corporate law requires, forbids, or enables. The main qualification to this claim is that many EC corporate law rules impose a small burden on each company to pay for the services of a professional or a public body. Examples are:

a. the First Council Directive's requirement that the company statutes and any amendments to those documents "be drawn up and certified in due legal form" (such as through public notaries in countries where this category of professional exists) or subject to "preventive control, administrative or judicial;"196

194 Cf. Eric Nowak, Investor Protection and Capital Market Regulation in Germany, in THE GERMAN FINANCIAL SYSTEM 425, 432 (Jan Pieter Krahnen \& Reinhard H. Schmidt eds., 2004) ("[I]n Germany ... disclosures [as mandated by the first insider trading directive] have been misused by some issuers as a public relations tool, while many other issuers have not disclosed a single statement ... Nevertheless, ad hoc disclosure activity of domestic issuers increased sharply, rising from 991 notifications in 1995 to 5057 disclosures in 2000, and falling ... [to] 3781 in $2002 \ldots .$. ..).

195 See Gerard Hertig \& Joseph A. McCahery, Company and Takeover Law Reforms in Europe: Misguided Harmonization Efforts or Regulatory Competition?, 4 EUR. BuS. ORG. L. REV. 179, 190-91 (2003) (doubting that the EU will at any time soon play any central role even in the areas of securities and accounting law); Hertig \& Lee, supra note 43 , at 359 (doubting that EC action in the area of securities law will ever be meaningful until a European securities and exchange commission is created). See also supra text accompanying note 44 .

196 First Council Directive, supra note 52, art. 10. In Spain, public notaries and especially Company Registrar officials extract significant fees from the preventive control of the validity of company statutes. See Jesús Alfaro Águila-Real, Lowering Legal Barriers to Entry Through Technology Without Touching Vested Interests: The Spanish Sociedad Limitada-Nueva Empresa, 5 EUR. BUS. ORG. L. REV. 449, 456-67 (2004) (describing how control of statutory compliance of articles of association by the Registrar has been a legal barrier to market entry). 
b. the First, Second, Third, Sixth, Eleventh, ${ }^{197}$ and Twelfth Council Directives' provisions imposing publicity in the company register of certain facts or documents; companies will have no choice but to buy the "disclosure services" provided by the relevant public bodies, turning to professionals or corporate services firms in complying;

c. the accounting directives, that have, in at least in some of the Member States, led to an upgrade of accounting rules and practices, thereby inflating the demand for accountants' services;

d. the mandatory bid rule: given the sums at stake, potential acquirers will inevitably seek the help of a top law firm in order to avoid it, unless of course they want to acquire all of the target's shares for cash anyway. ${ }^{198}$

Even avoidable rules can induce companies to pay for professional services for compliance. When the compliance costs, including the fees for the professional services, are lower than the avoidance costs (again, including the cost of legal advice), avoidable rules will be complied with and the professional services acquired. Such is often the case with the Second Council Directive's rules requiring an expert opinion for non-cash contributions.

While the burden of such rules is mostly trivial from the point of view of an individual company (especially well-established ones) in the aggregate, by inflating the demand for professional services, they secure significant benefits for the professionals and public officials providing those services. Further, since the burden on businesses has a fixed component, these rules have a disproportionate impact on smaller firms. Therefore, their overall effect is to raise, if only marginally, the barriers to entry into the European markets by making it more expensive to adopt the corporate form.

The same ultimate effect of increasing the cost of doing business of course comes from the Eighth Council Directive, which defines the professional qualifications of persons in charge of the

197 Eleventh Council Directive 89/666, 1989 O.J. (L 395) 36.

198 See Enriques, supra note 183, at 794-95 (highlighting that the directive potentially increases the scope of exemptions and price discounts, as well as the national supervisory authorities' discretion in granting them). 
compulsory auditing of a company's accounts ${ }^{199}$ and therefore raises a legal barrier to entry into the market for auditing services, with a predictable impact on the price for such services.

A general feature of EC corporate law also leads to higher costs - it undeniably increases the complexity of national corporate laws, ${ }^{200}$ making them more institutionally differentiated. ${ }^{201}$ Secondary EC corporate law adds two layers of rules to those at the national level. Member States' law must be consistent with EC directives and regulations, which in turn must be consistent with the EC Treaty.

Lawyers can reap economic benefits from the complexity of the law. ${ }^{202}$ As Gillian Hadfield aptly points out, complexity is one of the causes of the substantial deviation in the market for legal services from the competitive model. ${ }^{203}$ Among other things, complexity "is responsible for the credence nature of legal services... mak[ing] price and quantity in the market predominantly the result of beliefs and wealth, rather than of cost." 204

In the case of securities law directives and regulations adopted under the Lamfalussy approach, the picture is even more complex than in other corporate law areas. Here there are two layers of secondary EC law and a third layer of "quasi-law" - framework (or Level 1) directives and regulations contain the main principles and

199 See supra note 191 and accompanying text.

200 Cf. CHEFFINS, supra note 66, at 448 ("[T]he changes that have taken place [as a result of the EC company law harmonization program] have often made it more difficult for a resident of a Member State to know what the situation is with his own legislation while doing little to inform him about what the law is in other EU countries.").

201 Peter Schuck identifies four features of a complex legal system: density, technicality, indeterminacy, and, relevant for our purposes, institutional differentiation. Peter H. Schuck, Legal Complexity: Some Causes, Consequences, and Cures, 42 DUKE L.J. 1, 3-4 (1992). The term "institutional differentiation" refers to the fact that some legal systems "contain a number of decision structures that draw upon different sources of legitimacy, possess different kinds of organizational intelligence, and employ different decision processes for creating, elaborating, and applying the rules." Id. at 4.

202 See Halbhuber, supra note 27, at 1412 (noting "the increased complexity of national company laws brought about by the harmonizing programme" and commenting that "[s]uch complexity is bound to benefit lawyers able to handle it").

203 See Gillian K. Hadfield, The Price of Law: How the Market for Lawyers Distorts the Justice System, 98 MiCH. L. REV. 953, 995-96 (2000) (describing the market distortions stemming from complex laws).

204 Id. at 995 . See also id. at 995-96 (providing further insights on the beneficial effects of legal complexity for lawyers). 
rules; Level 2 directives and regulations contain more detailed provisions and, thanks to the smoother legislative process, can be modified more often to adapt to market and technological changes. In addition to these two layers, the Lamfalussy approach also provides for a third layer, in which the Committee of European Securities Regulators ("CESR") issues guidelines for the implementation and uniform interpretation of Level 1 and Level 2 measures. ${ }^{205} \mathrm{Ar}-$ guably, the documents produced by CESR to fulfil its Level 3 tasks also have to be taken into account by national securities regulators and, as a consequence, by lawyers when construing national rules. Note that not only is the law here more complex because of an additional layer of rules, but since the legislative landscape is bound to change more often, keeping up with it will be a further justification for charging a higher price for legal advice. New rules always imply greater uncertainty and, hence, a higher legal risk, due to the absence of precedents and widely shared interpretations.

Finally, Section III has shown that many EC corporate law provisions are more or less easily avoidable. When compliance costs (including lost-profit opportunities) are higher than the avoidance costs, companies will avoid them. To do so, as hinted before, advice from a lawyer will be necessary and usually sufficient. ${ }^{206}$ Therefore, avoidable rules raise the cost of doing business and corporate lawyers' fees. On the margin, they may also raise the cost of some transactions to the point that it is not convenient to carry out them.

Secondary EC corporate law provisions such as those described can finally be seen as aiming to protect the benefits secured for interest groups in individual Member States by eliminating the risk of domestic companies' (re)incorporating in other EC jurisdictions without such rules. ${ }^{207}$

To conclude, EC intervention in this area is like a cartel aiming

205 For a more detailed description of the Lamfalussy approach, see FERRAN, supra note 24, at 61-84. See also id. at 100 (predicting that the Level 3 standards and guidelines will "move into the foreground" once the Level 1 and Level 2 measures implementing the Financial Services Action Plan are adopted, even possibly into areas uncovered by secondary EC legislation).

206 See supra note 165 and accompanying text. The commentary by Eilís Ferran on Chaston v. SWP Group plc is especially interesting.

207 See Carney, supra note 133, at 317 ("While the stated reason for harmonization [of Member States' company law] was at least in part to avoid a race to the bottom, it could also be viewed as a means of protecting the special interest legislation previously obtained by powerful interest groups.").

Published by Penn Law: Legal Scholarship Repository, 2014 
to protect or increase the monopolistic rents of well-defined interest groups, especially professionals providing corporate-lawrelated services.

\subsubsection{EC corporate law and the dynamics of EU national laws}

The presence of a centralized lawmaker affects how corporate law is produced and evolves within the EU in various ways.

\subsubsection{Preemptive changes of national corporate laws}

First of all, Member States have sometimes preemptively reformed their company laws so as to anticipate, guide, or, in any event, affect the outcome of harmonization efforts. For instance, in the 1960s, Germany and France enacted their corporate law reforms with the secondary purpose of displaying more modern laws, from which the Commission, in their view, might have drawn inspiration for its first harmonization steps. ${ }^{208}$

More recently, a good example of a proactive move by a Member State with the clear purpose of affecting the outcome of harmonizing efforts at the EC level is that of Germany and its rules on takeover defenses. In Jeffrey Gordon's reading, the anti-takeover provision in the German law on takeovers was "a bargaining chip in a kind of trade negotiation, a raising of barriers designed to precipitate a crisis and force a new round of negotiations that would lower trade barriers-here, takeover protections-across the board." 209 Of course, an alternative and more straightforward reading is that the anti-takeover provision was a reaction to the Mannesmann takeover and to prior pro-takeover policy choices made by the German Government. ${ }^{210}$ Even from this perspective, however, the 2001 anti-takeover policy choice can at the same time be viewed as an effective way to contrast the Commission's attempt to adopt the modified passivity rule EU-wide, by credibly putting Germany's weight on a different policy choice.

208 See ERIC STEIN, HARMONIZATION OF EUROPEAN COMPANY LAWS: NATIONAL REFORM AND TRANSNATIONAL COORDINATION 92-102 (1971) (noting that in the 1960s Germany completed its company law reforms to strengthen its position in the EC framework).

209 Jeffrey N. Gordon, An American Perspective on Anti-Takeover Laws in the EU: The German Example, in REFORMING COMPANY AND TAKEOVER LAW IN EUROPE, supra note 95 , at 541, 547.

210 See Cioffi, supra note 84 , at 385-88 (discussing how the Mannesmann takeover and the mounting opposition to the draft EU Takeover Directive influenced Germany's takeover law reform).

https://scholarship.law.upenn.edu/jil/vol27/iss1/1 
In the United States, according to Roe's thesis, the federal authorities shape corporate law either by direct intervention or because "Delaware players know that the federal government can take away their corporate lawmaking power in whole or in part" 211 and therefore act in ways that federal authorities will not dislike. ${ }^{212}$ Something close to the reverse seems to be true in Europe. Member States reform their corporate laws in order to affect the outcome of EC institutions' initiatives and let these institutions adopt rules that they already have in place or that they would introduce anyway, while they are usually able to block EC developments that they (or, rather, their businesses) dislike.213 In other words, while in the United States, according to Roe, Delaware adapts to federal law and politics, in the EU, it is the EC that adapts to Member States' laws and politics. In the interaction between Member States and the EC, however, national laws may change in anticipation of possible policy initiatives at the EC level, as takeover law developments in Germany suggest.

\subsubsection{EC corporate law as a cartel}

Further, EC corporate law can also be viewed as a cartel among national legislators. ${ }^{214}$ Like any anticompetitive agreement, it may secure monopoly rents, increase consumer (societal) welfare, or both. It is impossible to say whether EC corporate law provisions, as a whole or one by one, would withstand scrutiny under a "rule of reason" analysis. But at least three implications can be drawn from the characterization of EC corporate law as a cartel.

First, the risk exists that, like any cartel, EC institutions may abuse their monopoly power. What is taking place in the area of securities law - with overactive EC institutions issuing Level 1 and Level 2 measures and Level 3 guidelines every other month or so with no realistic prospect that this is only a temporary phenomenon 215 - can be seen as an illustration of how the EC monopoly

211 Roe, supra note 1 , at 592.

212 See id. at 632 (arguing "that Delaware moved roughly in line with some sort of federal gravitional pull" in the 1980s and 1990s).

213 See infra text accompanying notes 248-250.

214 See supra text following note 207.

215 See When in Doubt Just Do Nowt, Fin. TIMEs (London), Jan. 24, 2005, at 16 (reporting the Internal Market Commissioner's pledge not to issue important legislative proposals in 2005 in the financial markets area, but also citing a report by Houston Consulting, a company that tracks the Financial Services Action Plan, according to which "78 EU financial services measures are in the pipeline"). 
power may be abused by engaging in excessive innovation. ${ }^{216}$ An ever-changing legal environment greatly increases the compliance costs of EC securities law. In fact, businesses and their consultants have to make the organizational and operational changes required by every regulatory update. Further, the Lamfalussy method may worsen the already questionable quality of EC securities law. That is, if rules are easy to change, it may be seen as more acceptable for them to be badly worded, inconsistent, or simply wrong. In other words, given the chance to legislate more swiftly, EC institutions, which are already prone to produce poor quality rules due to the complex art of reaching far-fetched political compromises and to the absence of regulatory competition restraining them, may just end up producing bad rules more often than before. ${ }^{217}$ This risk may well counteract the positive effect of greater changeability of rules, specifically, that mistaken rules can themselves be repealed more easily.

Second, from a dynamic perspective, in areas covered by harmonization, experimentation with new regulatory solutions by single jurisdictions is more difficult, if not ruled out altogether.218 Poison pills provide a good illustration of this point. These defensive devices are said to be unfeasible under European corporate laws, due to the "protection for preemptive rights and barriers to discriminatory share issuances [that] ... are buttressed by the Second Company Law Directive." 219 Recent developments in Italian law show that there may be ways around such protections and barriers, depending on how broadly the Second Council Directive's provisions are construed. Under the 2003 Italian corporate law, companies may issue "participating financial instruments" 220 non-voting or limited voting securities with cash flow rights possibly identical to those pertaining to shares, but which are explicitly

216 Cf. Ian Ayres, Supply-Side Inefficiencies in Corporate Charter Competition: Lessons from Patents, Yachting and Bluebooks, 43 U. KAN. L. REV. 541, 558-59 (1995) (suggesting that Delaware may engage in excessive innovation of its corporate law thanks to its market power).

217 Cf. FERRAN, supra note 24, at 57 (noting the "risk that a system that makes it easier to make laws could remove a de facto check on excessive legalism and increase the overall regulatory burden").

218 See, e.g., ROBERTA ROMANO, THE GENIUS OF AMERICAN CORPORATE LAW 132 (1993) ("[B]y mandating a floor, [harmonization] severely reduces the returns from innovation.").

219 Gordon, supra note 209, at 551 n.23.

220 C.C. art. 2346 , 16

https://scholarship.law.upenn.edu/jil/vol27/iss1/1 
not treated as shares according to the law.221 Thus, a company's board of directors, provided that the company's charter authorized them to do so, may issue such "non-share shares" without the need to grant existing shareholders preemption rights and possibly in favor of shareholders holding less than a specified percentage of the company's capital.222 They may also issue securities incorporating an option to purchase such non-share shares at a heavy discount and grant the board the power to redeem such rights. It seems that now there will be a device quite similar to a poison pill available to Italian companies. The most important difference would be that the general meeting, competent on charter amendments, would have to entrust the board with the power to adopt the Italian-style poison pill. However, this could be easily done at the IPO stage or before the dominant shareholder divests its controlling stake.

Yet, the risk of a court declaring the Italian-style poison pill illegal would be high, especially in light of the provision granting shareholders the preemption right on newly issued shares. ${ }^{223}$ In fact, Italian corporate law scholars and judges often tend to argue that mandatory corporate law rules should apply by analogy to cases similar to those explicitly covered.224 The presence of an EC directive imposing preemption rights would add further arguments in favor of the illegality of this defensive device, thus increasing the legal risk attaching to it. And this would be despite that, as a matter of EC law, it is far from certain that such a device would violate the Second Council Directive provisions on equality

221 See, e.g., Luca Enriques \& Giuseppe Scassellati Sforzolini, Adeguamenti Statutari: Scelte di Fondo e Nuove Opportunità nella Riforma Societaria [Statutory Updates: Strategic Options and New Opportunities in Reformed Corporate Laws], 2004 NOTARIATO [NOTARY REVIEW] 69, 79 (discussing "non-share shares").

222 Cf. Matteo Gatti, OPA e Struttura del Mercato del Controllo SOCIETARIO [TENDER OFFERS AND CORPORATE CONTROL TRANSACTIONS] 360-63 (2004) (considering the hypothesis of a new issue of shares and warrants similarly discriminating against a bidder and concluding that it would not violate the principle of equality of treatment of shareholders).

223 Luca Enriques, Quartum non datur: appunti in tema di "strumenti finanziari partecipativi" in Inghilterra, negli Stati Uniti e in Italia [There is no fourth option: notes on common shares in the UK, the USA and Italy], 68 BANCA BORSA TITOLI DI CREDITO [BANK, STOCK EXCHANGE AND NOTES] 166, 175 (2005).

224 Luca Enriques, Scelte pubbliche e interessi particolari nella riforma delle società di capitali [Public choices and private interests in the reformed corporate laws], 7 Mercato ConcorRenza Regole [MARKET, CoMPetition and Rules] 145, 173 (2005).

Published by Penn Law: Legal Scholarship Repository, 2014 
of treatment ${ }^{225}$ and preemption rights, ${ }^{226}$ as Belgian corporate law also appears to suggest with regard to the latter. ${ }^{227}$ To conclude, even avoidable EC company law rules may increase the legal risk attached to innovation in company law, thereby acting as a curb to it. 228

Finally, even in a post-Centros world it is most unlikely that any Member State will become active in the market for corporate charters. ${ }^{229}$ One reason why the Delaware-like scenario is unrealistic is that any Member State considering such a move must allow for the possibility that the EC would intervene to ban any corporate law feature that might actually attract incorporations.230 So, the very existence of EC lawmaking power in the corporate law areatogether with the fact that this power has been exercised fairly often over the decades - may work as a barrier to competition among jurisdictions.

This Article's thesis that EC corporate law consists principally of rules designed to safeguard benefits in favor of specific interest groups in part reinforces and in part weakens the claim that the EC's power to legislate in the corporate law area has a chilling ef-

225 Article 42 of the Second Council Directive 77/91, supra note 47, provides that "[f]or the purposes of the implementation of this Directive, the laws of the Member States shall ensure equal treatment to all shareholders who are in the same position." Arguably, if "non-share shares" are not covered by the Second Directive's provisions on new issues of shares, then article 42 does not apply to them. And, in any event, it is at least doubtful that the bidder and the other shareholders would be "in the same position."

226 If the reasoning in Advocate General's opinion in Meilicke applies, then it would be for the Member States to decide, according to their domestic laws, whether to strike down these "poison pills" on the ground that the company, by issuing them, has avoided the rules granting shareholders equal treatment and preemption rights. See supra note 152 and accompanying text.

227 Under Belgian law, other than during a takeover, the general meeting may authorize the board to issue parts bénéficiaries, i.e. non-share shares, giving existing shareholders no preemption rights on them. See Cristiano Cincotti, L'esperienza delle parts bénéficiaries belghe e gli strumenti finanziari partecipativi di cui all'art. 2346 c.c. [The Belgian "parts beneficiares" experience and the common shares], 2004 BANCA BORSA TITOLI DI CREDITO I [BANK, STOCK ExCHANGE AND NOTES] 221, 229 ; E-mail from Christoph van der Elst, Financial Law Institute, Ghent University, to Luca Enriques (Feb. 14, 2005 12:32 CET) (on file with author) (confirming the fact that such shares may be issued without any preemption rights).

228 Cf. Stefan Grundmann, The Structure of European Company Law: From Crisis to Boom, 5 EUR. BUS. ORG. L. REV. 601, 612-13 (2004) (emphasizing the advantages of regulatory competition "as a 'discovery device'")

229 See supra text accompanying note 9.

230 See, e.g., Enriques, supra note 9, at 1269-70 (arguing that prospective harmonization can discourage regulatory competition). 
fect on regulatory competition. On the one hand, if a Member State were ever to succeed in attracting reincorporations by devising rules that eliminate costs associated with well-organized interest groups (other than those already secured by EC corporate law, if there are any), there is a very good chance that the EC would step in to outlaw the attractive features of any such competing jurisdiction. On the other hand, the competing jurisdiction may be successful thanks to rules which attract businesses for other reasons (like a greater respect for private parties' determinations or even their pro-management tilt) without touching the interests of well-organized groups. In this case, provided that the charter mongering State succeeds in attracting a relevant number of companies, any attempt to rule out the attractive features of the competing jurisdictions would predictably fail, in light of the EC's inability thus far to win businesses' resistance against nontrivial harmonizing rules.

\subsubsection{EC corporate law legislation: a flourishing industry}

Finally, no matter how trivial the outcome, legislation in the corporate law area is indeed something serious: its ever more active production machinery matters not only to those who are directly engaged in the supply of EC corporate law, but also to businesses and professionals, who, normally through their associations, lobby EC and national institutions for or against the adoption of new EC measures.

As Table 1 and Appendix 1 show, after a slow start in the 1960s and 1970s, the output of EC corporate law has been steady and is now increasing fast. EC legislation needs continuous updating and maintenance. Further, according to many, and especially according to the EC Commission, EC corporate law has to cover more areas and to become more important.231

In short, EC corporate law matters as an active and growing lawmaking enterprise, first and foremost to those involved in supplying it, and second to those who may gain or lose from new rules and therefore lobby for or against them.

The following groups are involved in the supply of EC corporate law:

231 See MODERNISING COMPANY LAW AND ENHANCING CORPORATE GOVERNANCE IN THE EUROPEAN UNION, supra note 22, at 24-26 (displaying fourteen legislative initiatives extending the scope of EC corporate law and three changing the existing framework). 
1. politicians at the EC level (Commissioners and Members of the European Parliament), especially with regard to those rare policy issues that are politically sensitive, such as, recently, takeover defenses;

2. EC officials in charge of corporate law issues within the Internal Market Directorate General,232 now together with officials working at the CESR in Paris;

3. officials working on these issues within the European Council's Permanent Representatives Committee ("COREPER");

4. national politicians dealing with such issues, again especially with regard to politically sensitive issues;

5. national public officials having a part in Council meetings, in their preparation and/or in the implementation of directives once approved;

6. lawyers and law professors involved as advisers to lawmakers at the EC level (when EC measures are drafted) and at Member State level (both when EC measures are drafted and when they are to be transposed); 233

232 Directorate General F (Free Movement of Capital, Company Law and Corporate Governance) has a Unit in charge of "free movement of capital and financial integration," a Unit in charge of "company law, corporate governance and financial crime," a Unit in charge of "accounting" and one in charge of "auditing," while Directorate General G (Financial Services Policy and Financial Markets) has, among others, a unit in charge of "securities markets." European Commission, DG Internal Market and Services, Directorate General Internal Market and Services (2006), http://www.europa.eu.int/comm/dgs/internal_market/docs/ organigramme/organi_en.pdf.

233 The importance of lawyers and law professors in the debate and in the process of EC corporate law production can hardly be overestimated. Traditionally, the Commission has requested the advice of prominent corporate law professors and practitioners around Europe in drafting directives and getting ideas on how to proceed towards more comprehensive harmonization. See STEIN, supra note 208, at 316 ("[A] number of national company law experts ... [were] commissioned to prepare comparative studies on selected aspects of national laws. These studies would contain more or less specific suggestions as to which rules could or should be coordinated and in what way."); see also Pierre Van Ommeslaghe, La Première Directive du Conseil du 9 Mars 1968 en Matière de Sociétées [The first Directive of the Council of March 91968 regarding corporations matters], 5 CAHIERS DE https://scholarship.law.upenn.edu/jil/vol27/iss1/1 


\section{Brussels-based lobbying professionals and people work- ing for EC-level industry associations. ${ }^{234}$}

DROIT EUROPÉEN [J. EUR. LAW] 495, 498 (1969) (describing the primary role played by such company law experts in the drafting of the early company law directives). Most recently, the Commission renewed this tradition when it appointed the High Level Group of Company Law Experts, comprising seven leading European lawyers. Report of the High Level Group of Company Law Experts on a Modern Regulatory Framework for Company Law in Europe (Nov. 4 2002), in REFORMING COMPANY AND TAKEOVER LAW IN EUROPE, supra note 95, at 925, 1058. The Group helped the Commission draft a new takeover directive proposal. Report of the High Level Group of Company Law Experts on Issues Related to Takeover Bids, in id. at 825, 829. Then the Group provided it with an ambitious agenda for post-Enron reforms and for the modernization of EC corporate law. See Report of the High Level Group of Company Law Experts on a Modern Regulatory Framework for Company Law, in id. at 933-54 (making recommendations on corporate governance and restructuring). Unsurprisingly, the Group advocates the creation of "a more permanent structure which could provide the Commission with independent advice on future regulatory initiatives in the area of EU company law." Id. at 961; see Hertig \& McCahery, supra note 195, at 192 (arguing that a similar body would unduly favor state intervention in company law matters and may be prone to interest groups pressure). In October 2004, the Commission has created a European Corporate Governance Forum "to help the convergence of national efforts, encourage best practice and advise the Commission." Frits Bolkestein, Corporate Governance in the European Union (Oct. 18, 2004), available at http://www.europa.eu.int/rapid/pressReleasesAction.do?reference $=$ SPEECH $/ 04 / 460 \&$ format $=$ HTML\&aged $=0 \&$ language $=\mathrm{EN}$ \&guiLanguage=en. More recently, the Commission has declared its "intention to set up a consultative committee called the Advisory Committee on Corporate Governance and Company Law that would enable it to obtain technical advice on the implementation of the 2003 Company law and Corporate Governance Action Plan." Call for Applications for the Establishment of the Advisory Committee on Corporate Governance and Company Law, available at http://www.europa.eu. int/comm/internal_market/company/docs/advisory-committee/callapplications-2004-12_en.pdf.

The importance of lawyers is far from peculiar to EC corporate law making. The same is in fact true, for instance, of lawyers in the United States, Germany, and Italy. See Kahan \& Kamar, supra note 132, at 705 ("The driving force behind many [U.S.] corporate statutes is corporate lawyers."); Christian Kirchner et al., Regulatory Competition in EU Corporate Law after Inspire Art: Unbundling Delaware's Product for Europe 11 n.27 (Univ. of Ill. Coll. of Law, Law \& Econ. Working Paper No. 17, 2004), available at http://law.bepress.com/cgi/viewcontent.cgi?article $=1015 \&$ context=uiuclwps ("Law professors, through the participation on government appointed commissions, play a significant role in law reform in ... Germany."); Enriques, supra note 224, at 156-57 (reporting that thirty-three out of the thirty-five components of the Commission in charge of drafting the Italian corporate law reform of 2003 were lawyers, and among them twenty-four were also law professors).

234 See generally Roland Vaubel, The Political Economy of Centralization and the European Community, 81 PUB. CHOICE 151, 154 (1994) (highlighting that lobbyists at the central level of government will favor centralization of lawmaking). 
EC corporate law matters to these groups in various ways. First of all, these groups (plausibly with the exception of lobbying professionals) usually share a genuine belief in the virtues of harmonization of EU corporate laws, seeing it as a tool both to achieve the objective of market integration and to have better corporate laws in place across the EU.

Second, and more cynically, all these groups also have an interest in keeping an active lawmaking process going and, even more, in expanding the areas covered by EC corporate law, whatever its content. This is the case of politicians and bureaucrats at the EC level, of lobbyists as a group, and of lawyers and law professors involved as advisers. 235 Not only a greater scope for EC corporate law ${ }^{236}$ but also a more active EC corporate lawmaking industry will increase the power and prestige of all these groups. This is also the case of national-level bureaucrats in charge of implementation and of lawyers and law professors serving as their advisors, often the same people following the legislative works leading to the adoption of the directives for their respective countries.

As a matter of fact, most changes in national corporate law in the last thirty-five years have been the result of EC directives, so that apparently EC corporate law production has inflated the national "demand" for legislative work in this field,237 leading in turn to greater support for new EC initiatives from national legislative bureaucracies and corporate law scholars. Some of the national bureaucrats, politicians, and advisers will also favor EC legislation so as to develop a pro-European reputation, with a view to being

235 See id. at 153-54. Individual lobbyists will do their best to avoid EC legislation on behalf of their clients and employers in order to increase their chances of being assigned the same work again later on, in light of the EC Commission's insistence on its harmonization projects as exemplified by the story of the Takeover Directive. As a group, however, Brussels's lobbyists can only gain from an evergreater amount of EC legislation, because interest groups opposing it will sooner or later take action in order to have it repealed or changed. Moreover, EC legislation usually generates further legislation in the form of amendments, attempts to reach a higher level of harmonization, updates and the like.

236 As Giandomenico Majone observes, "the desire of the Commission to increase its influence [is] a fairly uncontroversial behavioral assumption." Giandomenico Majone, Regulating Europe: Problems and Prospects, in JAHRBUCH ZUR STAATS- UND VERWALTUNGSWISSENSCHAFT 1987/88 [YEARBOOK OF POLITICAL AND ADMINISTRATIVE SCIENCE] 159, 167 (Thomas Ellwein et al. eds., 1989).

237 This does not contradict the view that EC corporate law is trivial. It only shows that EC corporate law inflates the demand for corporate law reform services by requiring Member States to review their corporate laws, however trivial, more often than they would do otherwise. 
promoted to a position in Brussels. ${ }^{238}$

For lawyers and legal scholars involved in the production of EC corporate law as advisers to the Commission or to national governments, the process itself may have a consumption-good component, such as "the chance to reflect and consult with peers in a nonadversary setting about ideal statutory solutions to various problems - the counterpart of academic conferences." 239

Politicians and bureaucrats at national and EC level alike will further favor EC legislation that benefits specific interest groups, the former to secure their votes or campaign contributions, the latter to increase their power and prestige among such groups, possibly with a view to jobs in the private sector later on. ${ }^{440}$ National politicians and bureaucrats may also favor EC legislation in this area whenever it may raise the cost of doing business in other Member States to the same level as in their home state, thereby securing benefits in favor of the relevant national interest groups. ${ }^{241}$

Turning from the suppliers of EC corporate law to those who

238 See Vaubel, supra note 234, at 157 ("Centralization and cooperation with the central government are advocated by those lower-level politicians and bureaucrats who hope to be promoted to the central government."); Roland Vaubel, The Public Choice Analysis of European Integration: A Survey, 10 EUR. J. POL. ECON. 227, 233 (1994).

239 William J. Carney, The Production of Corporate Law, 71 S. CAL. L. REV. 715, 725 (1998). EC corporate law has a consumption good component for European corporate law professors in general, because it provides a common ground for research in this area of law. See also STEIN, supra note 208, at 193 (reporting that even back in the 1960s "[t]he interest generated by the Commission's [early] work has led to what one may call a flowering of comparative company law studies in the universities and in the some forty new centers of European studies"). EC company law also justifies (and helps find funding for) cross-border work and international conferences much better than mere comparative curiosity. Similarly, as Harald Halbhuber notes, "[f]ar from deploring the confusion created by directives, some German authors praise it as an intellectual challenge, a veritable comparative lawyer's paradise that would see national lawyers competing for influence on the ECJ's interpretation of the directives." Halbhuber, supra note 27, at 1412-13.

240 See STEIN, supra note 208, at 189-90 (reporting the case of a German civil servant who joined the Commission staff in 1958, "became director of the Directorate dealing with harmonization of company law ... [and] resigned in 1969 to become a member of the board of an insurance concern").

241 See supra text accompanying note 234. See also STEIN, supra note 208, at 232 (noting that Belgian and Italian experts pushed for immediate mandate of the obligation to disclose annual accounts). See generally Van Ommeslaghe, supra note 233, at 498-99 (noting that Belgium and Italy, which already imposed the publication of annual accounts by their companies, were among the most active proponents of a similar obligation at EC level). 
are bound to gain or lose from it, Section 4.1.2 identified the interest groups that benefit most. These groups actively demand EC corporate lawmaking. Accounts of the legislative process leading to the adoption of corporate law directives confirm that organized interest groups, such as accountants and their associations, have always played an active role in the production of EC corporate law, 242 consistent with the more general finding that interest groups play a prominent role in the EC lawmaking process. ${ }^{243}$

EC corporate law also serves lawyers' and law professors' interests, ${ }^{244}$ not only thanks to the increased complexity of the legal framework, but also because it may reduce "the regulatory surplus that parties could exploit by arbitraging jurisdictions." 245 Lawyers' and law professors' human capital is heavily invested in their domestic corporate laws and deeply connected with the mastery of their native language. Should private parties massively decide to opt out of their domestic laws, they would lose money and prestige. ${ }^{246}$ This helps explain why lawyers and law professors, quite

242 See STEIN, supra note 208, at 195-235 (examining the legislative history of the First Directive and highlighting how much the various interest groups were involved in the process); see also EDWARDS, supra note 23, at 118-19 (describing the proactive role of the German Institute of Public Accountants in the lawmaking process leading to the adoption of the Fourth Directive); Peter Walton, The True and Fair View and the Drafting of the Fourth Directive, 6 EUR. ACCT. REV. 721, 722 (1997) (noting that "[i]n 1965 the Commission asked the accounting profession in the ... six member states ... to constitute an expert group to prepare a report on the harmonization of accounting for listed firms," the work of which constituted the basis for the first draft of the Fourth Directive).

243 See generally J. Andrés Faiña Medin \& Pedro Puy Fraga, A Framework for a Public Choice Analysis of the European Community, 1988 ECONOMIA DELLE SCELTE Pubbliche [JOURnal of PUblic FinanCE AND Public CHOICE] 141, 154; see also Clive M. Schmitthoff, The Success of the Harmonization of European Company Law, 1976 EUR. L. REV. 100, 100 ("The eventual form in which the Council of Ministers approves an important legislative measure has often, in fact, been agreed between the officials of the Commission and the representatives of interested circles in the Member States.").

244 It is perhaps worth pointing out that lawyers (and law professors) play a two-fold role in corporate lawmaking, both on the supply side and on the demand side. See generally Larry E. Ribstein, Delaware, Lawyers, and Contractual Choice of Law, 19 DEL. J. CORP. L. 999, 1014-15 (1994) (analyzing the interaction of lawyers and other interest groups and their effect both on the supply side and demand side of state competition and commercial law in Delaware).

245 StEFANO LOMBARDO, REgulatory COMPETITION IN COMPANY LAW IN THE EUROPEAN COMMUNITY 193 (2002).

246 Id.; see also Halbhuber, supra note 27, at 1413 (emphasizing German corporate lawyers' interest "to protect the legal structures they are familiar with from interjurisdictional competition" and that German company law academics "risk loss of prestige and influence" if German businesses are organized under English https://scholarship.law.upenn.edu/jil/vol27/iss1/1 
aside from their genuine belief in the virtues of harmonization, usually favor it. 247

Other groups, such as businesses and their associations or families holding controlling blocks in EU companies, far from pushing for EC intervention, ${ }^{248}$ have usually resisted EC's attempts to harmonize areas of law (in a nontrivial way). ${ }^{249}$ As Sections 2 and 3 have shown, on the whole their resistance has been effective,

law).

247 What is argued here is not inconsistent with the claim that directives and regulations issued are thus far mostly trivial. First, they may be trivial due to the unsuccessful attempt to harmonize in a more effective way. Second, those advocating the adoption of corporate law directives and regulations plausibly perceive them to be less trivial than they are.

248 Desmond McComb makes this point with regard to accounting directives: "The accounting directives have been a prime example of legislation from above in the almost total absence of evident social need or demand." Desmond McComb, Accounting, in EUROPEAN BUSINESS LAW: LEGAL AND ECONOMIC ANALYSIS ON INTEGRATION AND HARMONIZATION, supra note 65.

249 For instance, both the Union des Industries de la Communauté européenne ("UNICE"), the main association of European industrialists, and the Féderation Bancaire opposed most proposed rules to be inserted in the Second Directive. STEIN, supra note 207, at 319-26; see also Lannoo, supra note 41, at 292 ("Member States and industry prefer to keep control over corporate control in their hands."). With specific regard to accounting directives, see also Graham Diggle \& Christopher Nobes, European Rule-making in Accounting: The Seventh Directive as a Case Study, 24 ACCT. \& BUS. RES. 319, 330 (1994), stating that:

Governments will also respond to strong lobby groups.... These groups will be aiming to preserve the status quo, to maintain flexibility, to minimise costs, and so forth. One powerful example of the influence of corporate lobbyists is the inclusion of special Articles in the Seventh Directive that enable the unique consolidation practices of Unilever and Royal Dutch Shell to continue (Article 12 and 15).

One may see an exception to this in so-called global players' pressure for an EC regime allowing them to use the International Accounting Standards ("IAS"). Haller, supra note 32 , at 168 . However, one should note that for global players the first best solution would have been simply to have EC accounting directives scrapped so as to be able to use IAS, as opposed to the current EC regime in which individual accounts are still regulated by the Fourth Directive (unless Member States exercise the option article 5 of Regulation 2002/1606 grants them to have individual accounts drawn according to IAS), while consolidated accounts must be drawn up according to the IAS principles as endorsed by the EC. As a matter of fact, the adoption of IAS accounting principles by the EC mainly reflects the EC institutions' (and especially the Commission's) aim "to keep itself in the game of taking future influence in international accounting harmonization," id. at 164, also in the face of Member States' pro-active moves to allow global players to use IAS. For instance, in 1998, Germany allowed its listed companies to prepare consolidated annual accounts in accordance with internationally accepted accounting principles. See, e.g., Nowak, supra note 194, at 435 (describing new corporate laws that conform to international practices).

Published by Penn Law: Legal Scholarship Repository, 2014 
leading, with few exceptions, to a fair amount of trivial EC corporate law.

The most common view, at least among lawyers, is that the EC's failure to harmonize EC corporate law more meaningfully is the outcome of a game in which a public-interest-minded European Commission attempts to improve the fairness and efficiency of corporate law within the EU, while Member States, captive to the interests of national businesses, block or water down the proposals. And it may well be that the resistance by dominant interest groups at the national level has always prevented the adoption of nontrivial EC rules. ${ }^{250}$

Once we take the interests of suppliers of EC corporate law into account, however, one may take a more cynical view of the $\mathrm{EC}$ company law production process. One may regard the EC institutions' failure to issue nontrivial rules as the result of a different game, in which EC politicians and public officials (no matter whether, as the case may be, in perfect good faith) propose controversial, nontrivial rules often with the tacit or explicit support of one or more Member States already having such rules in place, while politicians and bureaucrats from Member States in which the proposed rules would harm specific interest groups oppose them on those groups' behalf. Eventually, this is a game Member States will always be pleased to play: not only are they usually able to block any meaningful legislation in this area, thereby acting as champions of the organized national interests opposing the EC measure, but should they fail to block it, they can always put the blame on the EC and on other Member States. While it is debatable whether the EU economies would be better off with more relevant EC corporate law rules in place, it is certain that, in the process, the interest groups resisting EC intervention will have spent time and money in national and European lobbying. ${ }^{251}$

250 Cf. Lucian A. Bebchuk \& Mark J. Roe, A Theory of Path Dependence in Corporate Ownership and Governance, 52 STAN. L. REV. 127, 165 (1999):

British managers, French and Italian controlling shareholders, and German codetermined firms may each prefer a system of corporate governance that radically differs from that preferred by the others. But... [t]hey might wish to preserve their positional advantage in their own firms and as such might all prefer to prevent European Union officials from imposing a common set of corporate rules.

251 Cf. Mary E. Kostel, A Public Choice Perspective on the Debate over Federal Versus State Corporate Law, 79 VA. L. REV. 2129, 2153-54 (1993) (positing that federal lawmaking involves greater lobbying expenditures by managers, while the legishttps://scholarship.law.upenn.edu/jil/vol27/iss1/1 
A good illustration is the process that resulted in toothless rules on takeover defenses. The EC first proposed a modified passivity rule clearly inspired by the English City Code. This was strongly opposed by corporate Germany, following the traumatic takeover of Mannesmann by Vodafone, and German members of the European Parliament followed suit. 252 The European Parliament's rejection led the Commission to raise the stakes and, on the advice of the High Level Group of Company Law Experts, ${ }^{253}$ to propose even more controversial rules which would hit dominant shareholders and incumbent managers around the EU unevenly, prohibiting some structural defenses against takeovers de facto while leaving others untouched.254

The European Parliament, following the advice of two academics, ${ }^{255}$ proposed amendments that would have extended the negative impact of the directive to other structural defenses, namely multiple voting capital structures, while again leaving others untouched. ${ }^{256}$ The strong opposition from Member States with dominant shareholders and incumbent managers who might lose the

lative outcome will be at best no less pro-manager than state corporate statutes, the added expense of managerial lobbying at the federal level being thus "pure waste").

252 See Cioffi, supra note 84, at 382-84 (describing the effects of the Mannesmann takeover and the response from German lawmakers).

253 See supra text accompanying note 233 (discussing the history of the High Level Group).

254 See Commission of the European Communities, Proposal for a Directive of the European Parliament and of the Council on Takeover Bids, art. 11, at 6, COM (2002) 534 final (Oct. 2, 2002) (declaring restrictions on the transfer of shares and on voting rights unenforceable and ineffective during the bid and imposing the breakthrough rule; no provision in the proposal addressed structural defenses such as pyramids and cross-holdings, and the Proposal disclaimed any intent to address multiple voting structures).

255 See Barbara Dauner Lieb \& Marco Lamandini, The New Proposal of a Directive on Company Law Concerning Takeover Bids and the Achievement of a Level Playing Field, With Particular Reference to the Recommendations of the High Level Group of Company Experts Set Up by the European Commission 36-57 (Eur. Parliament, Directorate-Gen. for Research, Working Paper, 2002), available at http://www.jura.uniduesseldorf.de/dozenten/noack/texte/sonstige/study.pdf (recommending that the provisions of art. 11 be extended to include multiple voting structures and urging additional changes to cover other areas not addressed by the proposed Directive).

256 See Committee on Legal Affairs and the Internal Market, Report on the Proposal for a European Parliament and Council Directive on Takeover Bids, at 23, COM (2002) 534 final (Dec. 8, 2003) (extending the breakthrough rule so as to neutralize multiple voting structures, but again addressing neither pyramids nor crossholdings). 
quasi-rents stemming from their incontestable control positions was finally successful: the rules were made optional, or else trivial. ${ }^{257}$ In the meantime, these groups conducted an impressive lobbying campaign both at the national and at the EC level.258 In other words, they spent a lot of money and effort to obtain what they wanted: nothing. ${ }^{259}$

Undeniably, the view provided here is a cynical perception of why EC corporate law matters. One may of course paint a more idealistic picture, in which what little has been achieved despite Member States' and businesses' resistance improved the quality of companies' disclosures, prevented companies from entering into value-destroying transactions, and, at the end of the day, improved the quality of corporate law and governance within the EU, also to the benefit of their (often too myopic) businesses or of their economies. In other words, the higher cost of doing business deriving from EC corporate law would be justified on efficiency grounds. This may well be. The point is that while the benefits of secondary EC corporate law are debatable at best, 260 especially in the light of the triviality of most of its rules, it is hard to deny that the cost of setting up a company and of carrying out certain transactions is higher as a consequence of EC law, that EC corporate law helps certain interest groups secure benefits, that the corporate law landscape is more complex than it would otherwise be, that EC corporate law has a curbing effect upon the dynamics of regulatory competition in this area of law, and finally that its lawmaking industry is busy and flourishing.

257 See supra text accompanying notes 84-94.

258 See, e.g., Christopher Brown-Humes \& Francesco Guerrera, Wallenberg Attacks EU Over Takeover Proposals, FIN. TIMES (London), Jan. 13, 2002, at 10 (giving voice to Swedish industrialist Jacob Wallenberg's opposition to plans to extend the breakthrough rule to multiple-voting shares and reporting that Wallenberg would meet European Commissioner Frits Bolkestein on that day).

259 See generally FREd S. MCCHESNEY, MONEY FOR NOTHING: POLITICIANS, RENT EXTRACTION, AND POLITICAL EXTORTION 2 (1997) (introducing a theory of how politicians may threaten legislative action in order to appropriate benefits or quasirents from private actors who are seeking to avoid regulation).

260 As Section 4 has argued, one of the few achievements of EC corporate law is the requirement that companies over a given size prepare annual accounts according to certain rules, have them audited, and make them public. Brian Cheffins provides an excellent critique of the policy of imposing such requirements on smaller companies, mainly on grounds also valid for closely held companies. See CHEFFINS, supra note 66, at 512-21 (explaining why disclosure regulations are unnecessary for small businesses). 
4.2. One Possible Objection: Are Member States' Corporate Laws Also Trivial?

Before concluding, it may be worth countering a possible objection to our analysis thus far: that the same analysis with regard to individual Member States might well conclude that their corporate laws are no more important. Undeniably, many national provisions are trivial, but some of them do matter greatly for businesses.

First of all, in some jurisdictions rules implementing trivial EC corporate law provisions are nontrivial, simply because their policymakers, lawyers, and judges take them seriously. For instance, this is the case for rules on contributions in kind in Germany. ${ }^{261}$ Second, though not technically part of corporate law, rules on codetermination do matter in countries that impose them, and it is no coincidence that no attempt to export codetermination through directives and regulations has ever succeeded.262 Third, domestic rules and doctrines on structural and non-structural defenses against takeovers are self-evidently relevant. Further, it is hard to deny that rules and doctrines on directors' duties and liability, related-party transactions, and shareholder suits against directors and dominant shareholders are nontrivial.

The same is true of a rule found in some Member States, which Jonathan Macey and I have termed the "recapitalize or liquidate rule," requiring that when "losses cause a firm's net assets to fall below some specified minimum level, the firm must either recapitalize or reorganize into a type of company with a legal capital requirement no greater than the remaining net assets." 263 If it fails to do so promptly, it must be wound up, and if the company is not liquidated, the directors are personally liable. Self-evidently, this rule plays a major role for "asset-light" companies and especially for companies near insolvency. ${ }^{264}$

To be sure, after the recent ECJ decisions on companies' free-

261 See Halbhuber, supra note 27, at 1406 n.109 (indicating that German law provides for "draconian sanctions to prevent evasion of these rules").

262 See, e.g., BUXBAUM \& HOPT, supra note 45, at 259-62 (explaining the difficulties in integrating codetermination requirements in European countries).

263 See Enriques \& Macey, supra note 60, at 1183-84 (citing such rules in place in Italy, France, Spain and Sweden).

264 Cf. Roberto Weigmann, Società per azioni [Corporations] 14 DIGESTO Discipline Privatistiche, Sezione Commerciale [Digest of Private SubJects, COMMERCIAL SECTION] 338, 423 (1997) (describing how loss of capital and insolvency are the most frequent causes of dissolution in Italy). 
dom of establishment, ${ }^{265}$ one may argue that State corporate laws have become trivial in the sense that companies may avoid national rules simply by reincorporating elsewhere.266 For the present, however, legal, tax, and other barriers to corporate law arbitrage, especially for already existing companies, are still high enough to preserve national corporate laws' relevance. ${ }^{267}$ In any event, the trivialization of national company laws due to the ECJ decisions would not itself make EC directives and regulations less trivial.

\section{CONCLUSION}

This Article has argued that secondary EC corporate law has thus far been trivial in that it has had and is having very little impact upon EU corporations' governance and management. First, it fails to cover core corporate law areas such as fiduciary duties and shareholder remedies. Second, the rules are under-enforced. Third, in the presence of very sporadic judiciary interpretation by the European Court of Justice, EC corporate law tends to be implemented and construed in different Member States according to local legal culture, and consistently with preexisting corporate law. Fourth, in the few instances in which it has introduced new rules, it has done so with respect to issues which Member States would most probably have legislated even in the absence of an EC mandate. Finally, most of its rules are optional, market-mimicking, unimportant, or avoidable. This cannot be said of national corporate laws, which still regulate core issues, sometimes even in an intrusive way, as in imposing passivity upon managers of target companies during a takeover or requiring companies to recapitalize or liquidate as assets fall below required levels.

265 See Case C-212/97, Centros Ltd. v. Erhvervs-og Selskabsstyrelsen, 1999 E.C.R. I-1483 (rejecting certain justifications for refusing to register a branch of a limited liability company from another Member State as counter to the EC Treaty); Case C-208/00, Überseering BV v. Nordic Construction Company Baumanagement GmbH, 2002 E.C.R. I-9971 (requiring Member States to allow companies which have moved to a given State to bring suits under contract law in that State under certain circumstances); C-167/01 Kamer van Koophandel v. Inspire Art, 2003 E.C.R. I-10155 (holding that national legislation applying domestic corporate law to companies of foreign Member States violates freedom of establishment).

266 Cf. Black, supra note 80, at 556, 558 (arguing that reincorporation renders avoidable every rule that is mandatory in one state and optional in another, provided that the costs of reincorporating are low enough).

267 See Enriques, supra note 9, at 1260-66.

https://scholarship.law.upenn.edu/jil/vol27/iss1/1 
There are, of course, due qualifications to the triviality thesis. First of all, a few rules or sets of rules indeed have had or are bound to have a meaningful impact on companies and their operations. Second, EC corporate law has increased the regulatory burden of corporate laws across the EU, correspondingly securing advantages for certain interest groups. Third, secondary EC corporate law has an impact on the evolution of European corporate laws and the dynamics of regulatory competition in various ways. In short, Member States interact with EC institutions in order to affect the outcome of its harmonization efforts and, in the process, alter their company laws to this purpose. EC institutions may abuse their monopoly power to impose rules on EU companies, especially by overly frequent legislative innovation. In areas covered by EC law (no matter how trivial), experimentation (however mildly) by competing jurisdictions is ruled out, or at least more difficult, especially when the EC measures involve comprehensive harmonization; the mere possibility of intervention in the area of corporate law may curb regulatory competition. Finally, its production has become an industry itself, employing many EC and national functionaries and lobbyists, and creating occasions for rent extraction by politicians.

EU institutions have recently become overactive in all areas of corporate law as defined here: in securities regulation, a number of Level 1 and Level 2 directives and regulations have been issued that attempt to completely harmonize securities law and to ensure greater uniformity in its enforcement as well. In accounting law, the Commission is playing an active role in the shaping of international accounting standards 268 and has proposed to reshape the regulation of auditing and accounting following the example of the Sarbanes-Oxley Act. 269 In core corporate law, an ambitious action

268 See, e.g., Frits Bolkestein, End the Carping over Accounting Standards, FIN. TIMES (London), Nov. 9, 2004, at 19 (reporting that the EC Commission has interacted with the IAS Board in order to obtain "improvements" of the International Financial Reporting Standards); see also Commission Regulation 2086/2004, 2004 O.J. (L 363) 1, 3 (EC) (endorsing IAS 39, but carving out its "full fair value option" and its hedge accounting provisions).

269 See Commission of the European Communities, Proposal for a Directive of the European Parliament and of the Council Amending Council Directives 78/660 and 83/349 Concerning the Annual Accounts of Certain Types of Companies and Consolidated Accounts, at 8-11, COM (2004) 725 final (Oct. 27, 2004) (laying out current and recommended accounting measures); Commission of the European Communities, Proposal for a Directive of the European Parliament and of the Council on StatuPublished by Pudit of Annual Accounts and Consolidated Accounts and Amending Council Di- 
plan is being transformed into EC law.270 Such activism might soon render the main thesis of this Article obsolete. If the experience so far is of any guidance, however, the final impact of all these efforts on national corporate laws and EU companies may well prove to be weaker than expected. Further, whatever the final outcome of the new trend toward harmonization, this Article provides a framework for assessing whether the forthcoming wave of EC legislation can escape the destiny of triviality thus far characterizing EC company law directives and regulations.

rectives 78/660 and 83/349, at 3, 12-14, COM (2004) 177 final (Mar. 16, 2004) (introducing "new requirements concerning the manner in which an audit should be carried out" and proposing further changes relating to statutory audits).

270 See Communication From the Commission to the Council and the European Parliament: Modernising Company Law and Enhancing Corporate Governance in the European Union - A Plan to Move Forward, supra note 22, at 7-22 (defining policy goals and concrete objectives); Directorate General for Internal Market and Services, Consultation on Future Priorities for the Action Plan on Modernising Company Law and Enhancing Corporate Governance in the European Union 2, http://europa.eu.int/ comm/internal_market/company/docs/consultation/consultation_en.pdf (providing an overview of the progress in the implementation of the Action Plan). 
APPENDIX 1. EC CORPORATE LAW DIRECTIVES AND REGULATIONS ${ }^{271}$

1. First Council Directive of 9 March 1968, on co-ordination of safeguards which, for the protection of the interests of members and others, are required by Member States of companies within the meaning of the second paragraph of Article 58 of the Treaty, with a view to making such safeguards equivalent throughout the Community, 68/151, 1968 O.J. (L 65) 8, amended by:

a. Council Directive 2003/58, 2003 O.J. (L 221) 13;

2. Second Council Directive of 13 December 1976, on coordination of safeguards which, for the protection of the interests of members and others, are required by Member States of companies within the meaning of the second paragraph of Article 58 of the Treaty, in respect of the formation of public limited liability companies and the maintenance and alteration of their capital, with a view to making such safeguards equivalent, 77/91, 1977 O.J. (L 26) 1, amended by:

a. Council Directive 92/101, 1992 O.J. (L 347) 64;

3. Third Council Directive of 9 October 1978, based on Article $54(3)(\mathrm{g})$ of the Treaty concerning mergers of public limited liability companies, 78/855, 1978 O.J. (L 295) 36;

4. Fourth Council Directive of 25 July 1978, based on Article $54(3)(\mathrm{g})$ of the Treaty on the annual accounts of certain types of companies, 78/660, 1978 O.J. (L 222) 11, amended by:

a. Seventh Council Directive of 13 June 1983, 83/349 (infra);

b. Council Directive of 27 November 1984, 84/569, 1984 O.J. (L 314) 28;

271 Updated to Dec. 31, 2004. Those directives or regulation in italics are measures that have already been cited in the Appendix or which will be cited further below. Those in square brackets are measures that have been repealed. 
c. Eleventh Council Directive of 21 December 1989, 89/666 (infra);

d. Council Directive of 8 November 1990, 90/604, 1990 O.J. (L 317) 57;

e. Council Directive of 8 November 1990, 90/605, 1990 O.J. (L 317) 60;

f. Council Directive of 21 March 1994, 94/8, 1994 O.J. (L 82) 33;

g. Council Directive of 17 June 1999, 99/60, 1999 O.J. (L 162) 65 ;

h. Directive of 27 September 2001, 2001/65, 2001 O.J. (L 283) 28;

i. Council Directive of 13 May 2003, 2003/38, 2003 O.J. (L 120) 22;

j. Directive of the European Parliament and of the Council of 18 June 2003, 2003/51, 2003 O.J. (L 178) 16;

5. [Council Directive of 5 March 1979, coordinating the conditions for the admission of securities to official stock exchange listing, 79/279, 1979 O.J. (L 66) 21, amended by:

a. Council Directive of 3 March 1982, 82/148, 1982 O.J. (L 62) 22;

b. Council Directive of 12 December 1988, 88/627 (infra); repealed by:

c. Directive of the European Parliament and of the Council of 28 May 2001, 2001/34 (infra);]

6. [Council Directive of 17 March 1980, coordinating the requirements for the drawing up, scrutiny, and distribution of the listing particulars to be published for the admission of securities to official stock exchange listing, 80/390, 1980 O.J. (L 100) 1, amended by:

a. Council Directive of 3 March 1982, 82/148, 1982 O.J. (L 
62) 22 ;

b. Council Directive of 22 June 1987, 87/345, 1987 O.J. (L 185) 81;

c. Council Directive of 23 April 1990, 90/211, 1990 O.J. (L 112) 24;

d. Directive of the European Parliament and of the Council of 30 May 1994, 94/18, 1994 O.J. (L 135) 1; repealed by:

e. Directive of the European Parliament and of the Council of 28 May 2001, 2001/34 (infra);]

7. [Council Directive of 15 February 1982, on information to be published on a regular basis by companies the shares of which have been admitted to official stock-exchange listing, 82/121, 1982 O.J. (L 48) 26, repealed by:

a. Directive of the European Parliament and of the Council of 28 May 2001, 2001/34 (infra);]

8. Sixth Council Directive of 17 December 1982, based on Article $54(3)(\mathrm{g})$ of the Treaty, concerning the division of public limited liability companies, 82/891, 1982 O.J. (L 378) 47;

9. Seventh Council Directive of 13 June 1983, based on the Article $54(3)(\mathrm{g})$ of the Treaty on consolidated accounts, 83/349, 1983 O.J. (L 193) 1, amended by:

a. Eleventh Council Directive of 21 December 1989 89/666 (infra);

b. Council Directive of 8 November 1990, 90/604, 1990 O.J. (L 317) 57;

c. Council Directive of 8 November 1990, 90/605, 1990 O.J. (L 317) 60;

d. Directive of 27 September 2001, 2001/65, 2001 O.J. (L 283) 28 ; 
e. Directive of the European Parliament and of the Council of 18 June 2003, 2003/51, 2003 O.J. (L 178) 16;

10. Eighth Council Directive of 10 April 1984, based on Article $54(3)(\mathrm{g})$ of the Treaty on the approval of persons responsible for carrying out the statutory audits of accounting documents, 84/253, 1984 O.J. (L. 126) 20;

11. [Council Directive of 12 December 1988, on the information to be published when a major holding in a listed company is acquired or disposed of, 88/627, 1988 O.J. (L 348) 62 , repealed by:

a. Directive of the European Parliament and of the Council of 28 May 200, 2001/34 (infra);]

12. [Council Directive of 17 April 1989, coordinating the requirements for the drawing-up, scrutiny, and distribution of the prospectus to be published when transferable securities are offered to the public, 89/298, 1989 O.J. (L 124) 8 , repealed by:

a. Directive of the European Parliament and of the Council of 4 November 2003, 2003/71 (infra);]

13. [Council Directive of 13 November 1989, coordinating regulations on insider dealing, 89/592, 1989 O.J. (L 334) 30, repealed by:

a. Directive of the European Parliament and of the Council of 28 January 2003, 2003/6 (infra);]

14. Eleventh Council Directive of 21 December 1989, concerning disclosure requirements in respect of branches opened in a Member State by certain types of company governed by the law of another State, 89/666, 1989 O.J. (L 395) 36;

15. Twelfth Council Company Law Directive of 21 December 1989 , on single-member private limited-liability companies, 89/667, 1989 O.J. (L 395) 40; 
16. Directive of the European Parliament and of the Council of 28 May 2001, on the admission of securities to official stock exchange listing and on information to be published on those securities, 2001/34, 2001 O.J. (L 184) 1, amended by:

a. Directive of the European Parliament and of the Council of 28 January 2003, 2003/6 (infra);

b. Directive of the European Parliament and of the Council of 4 November 2003, 2003/71 (infra);

c. Directive of the European Parliament and of the Council of 15 December 2004, 2004/109 (infra);

17. Regulation of 8 October 2001, on the Statute for a European Company (SE), 2001/2157, 2001 O.J. (L 294) 1;

18. Directive of 8 October 2001, supplementing the Statute for a European company with regard to the involvement of employees, 2001/86, 2001 O.J. (L 294) 22;

19. Regulation of the European Parliament and of the Council of 19 July 2002, on the application of international accounting standards, 1606/2002, 2002 O.J. (L 243) 1, implemented by:

a. Commission Regulation of 29 September 2003 and Annexes, adopting certain international accounting standards in accordance with Regulation 1606/2002, 1725/2003, 2003 O.J. (L 261) 1, amended by:

i. Commission Regulation of 6 April 2004, 707/2004, 2004 O.J. (L 111) 3;

ii. Commission Regulation of 19 November 2004, 2086/2004, 2004 O.J. (L 363) 1;

iii. Commission Regulation of 29 December 2004, 2236/2004, 2004 O.J. (L 392) 1;

iv. Commission Regulation of 29 December 2004, 2237/2004, 2004 O.J. (L 393) 1;

v. Commission Regulation of 29 December 2004, 
2238/2004, 2004 O.J. (L 394) 1;

20. Directive of the European Parliament and of the Council of 28 January 2003, on insider dealing and market manipulation (market abuse), 2003/6, 2003 O.J. (L 96) 16, implemented by:

a. Commission Directive of 22 December 2003, implementing Directive 2003/6 of the European Parliament and of the Council as regards the definition and public disclosure of inside information and the definition of market manipulation, 2003/124, 2003 O.J. (L 339) 70;

b. Commission Regulation of 22 December 2003, implementing Directive 2003/6 as regards exemptions for buy-back programmes and stabilisation of financial instruments, 2273/2003, 2003 O.J. (L 336) 33;

c. Commission Directive of 29 April 2004, implementing Directive 2003/6 of the European Parliament and of the Council as regards accepted market practices, the definition of inside information in relation to derivatives on commodities, the drawing up of lists of insiders, the notification of managers' transactions, and the notification of suspicious transactions, 2004/72, 2004 O.J. (L 162) 70;272

21. Directive of the European Parliament and of the Council on the Prospectus to be Published When Securities are Offered to the Public or Admitted to Trading and Amending Directive 2001/34, 2003/71, 2003 O.J. (L 345) 64, implemented by:

a. Commission Regulation Implementing Directive 2003/71 of the European Parliament and of the Council as Regards Information Contained in Prospectuses as well as the Format, Incorporation by Reference and

272 Directive 2003/6 is also implemented by Commission Directive 2003/125 of 22 December 2003, 2003 O.J. (L 339) 73. The latter directive, which implements the former "as regards the fair presentation of investment recommendations and the disclosure of conflicts of interest," does not deal with corporate law issues and is therefore not included in the list. 
Publication of such Prospectuses and Dissemination of Advertisements, 809/2004, 2004 O.J. (L 149) 1;273

22. Directive of the European Parliament and of the Council on Takeover Bids, 2004/25, 2004 O.J. (L 142) 12, (yet to be implemented with level 2 measures);

23. Directive of the European Parliament and of the Council on the Harmonisation of Transparency Requirements in Relation to Information about Issuers Whose Securities are Admitted to Trading on a Regulated Market and Amending Directive 2001/34, 2004/109, 2004 O.J. (L 390) 38.

273 See Comm. of Eur. Sec. Regulators, CESR's Recommendations for the Consistent Implementation of the European Commission's Regulation on Prospectuses No. 809/2004, CESR/05/054b, (2005), available at http://www.cesr.eu.org (introducing Level 3 legislative measures). 
APPENDIX 2. ECJ CASES INVOLVING SECONDARY EC CORPORATE LAW ISSUES 274

A. Proceedings concerning failure by Member States to implement directives:

1. Case C-136/81, Comm'n v. Italian Republic, 1982 E.C.R. 3547 (failure to transpose Second Directive);

2. Case C-148/81, Comm'n v. Kingdom of Belgium, 1982 E.C.R. 3555 (failure to transpose Second Directive);

3. Case C-149/81, Comm'n v. Grand Duchy of Luxembourg, 1982 E.C.R. 3565 (failure to transpose Second Directive);

4. Case C-151/81, Comm'n v. Ireland, 1982 E.C.R. 3573 (failure to transpose Second Directive);

5. Case C-390/85, Comm'n v. Kingdom of Belgium, 1987 E.C.R. 761 (failure to transpose three securities law directives);

6. Case C-17/85, Comm'n v. Italian Republic, 1986 E.C.R. 1199 (failure to transpose Fourth Directive);

7. Case C-157/91, Comm'n v. Kingdom of the Netherlands, 1992 E.C.R. I-5899 (failure to transpose two Articles of Eighth Directive);

8. Case C-95/94, Comm'n v. Kingdom of Spain, 1995 E.C.R. I-1967. This case was removed from the register;

9. Case C-191/95, Comm'n v. Federal Republic of Germany, 1998 E.C.R. I-5449 (failure to transpose First and Fourth Council Directives by failing to provide appropriate penalties as prescribed by those Directives);

10. Case C-272/97, Comm'n v. Federal Republic of Germany, 1999 E.C.R. I-2175 (failure to transpose Directive 90/605); 
11. Case C-185/98, Comm'n v. Hellenic Republic, 1999

E.C.R. I-3047 (failure to transpose Directive 92/101).

B. Preliminary rulings:

1. Case 32/74, Friedrich Haaga $\mathrm{GmbH}, 1974$ E.C.R. 1201 (First Council Directive);

2. Case 136/87, Ubbink Isolatie BV v. Dak- en Wandtechniek BV, 1988 E.C.R. 4665 (First Council Directive);

3. Case C-38/89, Ministère public v. Blanguernon, 1990 E.C.R. I-83 (citing Fourth Council Directive, but generally holding that national law implementing a directive has full force, even if other States have failed to implement it yet);

4. Case C-106/89, Marleasing SA v. La Comercial Internacional de Alimentacion SA, 1990 E.C.R. I-4135 (First Council Directive, but generally holding that national law has to be interpreted consistently with EC law);

5. Case C-381/89, Sindesmos Melon tis Eleftheras Evangelikis Ekklissias v. Greek State, 1992 E.C.R. I-2111 (Second Council Directive);

6. Joined Cases C-19/90 \& C-20/90, Karella v. Minister for Industry, Energy \& Technology, 1991 E.C.R. I-2691 (Second Council Directive);

7. Case C-83/91, Meilicke v. ADV/ORGA AG, 1992 E.C.R. I-4871 (decided on procedural grounds);

8. Joined Cases C-134/91 \& C-135/91, KerafinaKeramische und Finanz-Holding AG v. Greek State, 1992 E.C.R. I-5699 (Second Council Directive);

9. Case C-441/93, Pafitis v. Trapeza Kentrikis Ellados A. E., 1995 E.C.R. I-1347 (Second Council Directive);

10. Case C-234/94, Tomberger v. Gebruder von der Wettern GmbH, 1996 E.C.R. I-3133 (Fourth Council Directive); 
11. Case C-42/95, Siemens AG v. Nold, 1996 E.C.R. I6017 (Second Council Directive);

12. Case C-97/96, Verband deutscher DaihatsuHandler eV v. Daihatsu Deutschland GmbH, 1997 E.C.R. I-6843 (First and Fourth Council Directives);

13. Case C-104/96, Cooperatieve Rabobank 'Vecht en Plassengebied' BA v. Erik Aarnoud Minderhoud, 1997 E.C.R. I-7211 (First Council Directive);

14. Case C-367/96, Kefalas v. Elliniko Dimosio (Greek State), 1998 E.C.R. I-2843 (Second Council Directive);

15. Case C-275/97, DE \& ES Bauunternehmung v. Finanzamt Bergheim, 1999 E.C.R I-5331 (Fourth Council Directive);

16. Case C-373/97, Diamantis v. Dimosio, 2000 E.C.R. I1705 (Second Council Directive);

17. Case C-28/99, Criminal proceedings against Jean Verdonck, 2001 E.C.R. I-3399 (First Insider Trading Council Directive);

18. Case C-306/99, Banque internationale pour l'Afrique occidentale SA (BIAO) v. Finanzamt für Großunternehmen in Hamburg, 2003 E.C.R. I-1 (Fourth Council Directive);

19. Case C-182/00, Application Brought by Lutz $\mathrm{GmbH}, 2002$ E.C.R. I-547 (decided on procedural grounds);

20. Case C-167/01, Kamer van Koophandel v. Inspire Art Ltd. 2003 E.C.R. I-10155 (Eleventh Council Directive);

21. Joined Cases C-435/02 \& C-103/03, Axel Springer AG v. Zeitungsverlag GmbH \& Co. Essen KG, Hans Jürgen Weske, 2004 E.C.R. I- (First and Fourth Council Directives);

22. Case C-255/01, Markopoulos v. Anaptyxis, 2004 E.C.R. I (Eleventh Council Directive). 